\title{
The impact of the sandeel fishery closure on seabird food consumption, distribution, and productivity in the northwestern North Sea
}

\author{
Francis Daunt, Sarah Wanless, Simon P.R. Greenstreet, Henrik Jensen, \\ Keith C. Hamer, and Michael P. Harris
}

\begin{abstract}
In the North Sea, the lesser sandeel (Ammodytes marinus) is the target of an industrial fishery and the principal prey of many top predators. Because of concerns about potential effects on predators, the sandeel fishery off eastern Scotland was closed in 2000, and local sandeel abundance increased subsequently. To examine whether closure benefitted sandeel-dependent seabirds, we compared summer sandeel consumption, at-sea distributions, and breeding success of seven species with fishery removals and abundance of older (1+ group) and young-of-the-year (0 group) sandeels from 1996 to 2003. Breeding success of black-legged kittiwake (Rissa tridactyla), a species that has declined in recent decades, was related to abundance of both $1+$ group (the age class targeted by the fishery) and 0 group sandeels. The proportion of 0 group consumed by kittiwakes and proportion of the kittiwake population foraging in the area were linked to 0 group abundance. None of these parameters in the other seabird species were associated with sandeel abundance. Our results suggest that fishery closure can have a beneficial impact on top predators sensitive to variation in abundance of the target species, although environmental conditions before and after closure are also likely to be critically important.

Résumé : Dans la mer du Nord, le lançon équille (Ammodytes marinus) fait l'objet d'une pêche industrielle et il constitue la principale proie de plusieurs prédateurs supérieurs. À cause de préoccupations concernant les effets potentiels sur les prédateurs, la pêche commerciale aux lançons équilles au large de la côte est de l'Écosse a été fermée en 2000 et l'abondance locale des lançons a alors augmenté. Afin de vérifier si cette fermeture a été bénéfique aux oiseaux marins dépendants des lançons, nous avons comparé la consommation de lançons pendant l'été, la répartition en mer et le succès de la reproduction chez sept espèces en fonction des retraits de la pêche et de l'abondance des lançons de l'année (groupe 0) et des lançons plus âgés (groupe 1+) de 1996 à 2003. Le succès de la reproduction de la mouette tridactyle (Rissa tridactyla), une espèce en déclin au cours des dernières décennies, est relié à l'abondance des lançons, tant ceux du groupe 1+ (la classe d'âge ciblée par la pêche) que ceux du groupe 0. La proportion des lançons d'âge 0 consommée par les mouettes et la proportion de la population de mouettes qui recherche sa nourriture dans la région sont reliées toutes deux à l'abondance du groupe 0 . Aucune de ces variables chez les autres espèces d'oiseaux marins n'est reliée à l'abondance des lançons. Nos résultats indiquent que la fermeture de la pêche peut avoir un effet bénéfique sur les prédateurs supérieurs qui sont sensibles à la variation de l'abondance de l'espèce ciblée, bien que les conditions du milieu avant et après la fermeture puissent être aussi vraisemblablement d'importance primordiale.
\end{abstract}

[Traduit par la Rédaction]

\section{Introduction}

Closed or managed areas are a potential management option for safeguarding populations of targeted species and associated top predators (Ormerod 2003). However, decisions on the location and size of closed areas have been hindered by lack of data on the behaviour and mobility of the targeted species and ecosystem processes, including functional rela- tionships with top predators (Sale et al. 2005). Closed areas are a particularly attractive management option for sedentary, short-lived species that are subject to a directed fishery, because protected habitats support all age classes, and recovery is more rapid than with long-lived species (Gell and Roberts 2003; Sale et al. 2005).

In the North Sea, the lesser sandeel (hereafter sandeel), Ammodytes marinus, is a short-lived, shoaling fish closely

Received 14 December 2006. Accepted 26 July 2007. Published on the NRC Research Press Web site at cjfas.nrc.ca on 31 January 2008. J19703

F. Daunt, ${ }^{1,2}$ S. Wanless, and M.P. Harris. Centre for Ecology and Hydrology, Hill of Brathens, Banchory AB31 4BW, United Kingdom.

S.P.R. Greenstreet. Fisheries Research Services, Marine Laboratory, P.O. Box 101, 375 Victoria Road, Aberdeen AB11 9DB,

United Kingdom.

H. Jensen. Danish Institute for Fisheries Research, Charlottenlund Castle, DK-2920 Charlottenlund, Denmark.

K.C. Hamer. Ecology and Evolution Group, School of Biology, University of Leeds, Leeds LS2 9JT, United Kingdom.

${ }^{1}$ Corresponding author (e-mail: frada@ceh.ac.uk).

${ }^{2}$ Present address: Centre for Ecology and Hydrology - Edinburgh, Bush Estate, Edinburgh EH26 0QB, United Kingdom. 
associated with sandy sediments (Wright et al. 2000). These habitats are patchily distributed, resulting in distinct, reproductively isolated populations (Gauld 1990; Proctor et al. 1998). Sandeels are the staple diet of many top predators (Furness 2002; Greenstreet 2006) and were until recently the target of the largest single species fishery in the North Sea (ICES 2004). There is considerable concern that the fishery adversely affects seabirds (Monaghan 1992; Furness 2002), because it coincides with their breeding season when energetic demands are high and in some areas overlaps spatially with seabird foraging areas (Wright and Begg 1997). On a North Sea scale, natural mortality is larger than fishing mortality (ICES 2005b). However, landings by the fishery are typically much higher than the amount of fish eaten by seabirds (Furness 2002), so the fishery is more likely to impact the seabirds than vice versa. Poor seabird breeding success has been repeatedly linked to low availability of sandeels (Monaghan et al. 1989; Rindorf et al. 2000).

The fishery targets mainly sandeels aged 1 year and older (hereafter referred to as 1+ group). Sandeels spend much of the year buried in sandy substrates, entering the water column briefly in winter to spawn and from March to June to feed (Winslade 1974). 1+ group sandeels are important in the diet of many seabird species foraging in the North Sea early in the season (Furness and Tasker 2000). Most species then switch to young-of-the-year (hereafter referred to as 0 group) sandeels as they become available from mid-May onwards (Lewis et al. 2001; Wilson et al. 2004). Impacts on seabirds in the current year depend on the timing of the fishery relative to the timing of the switch in diet from $1+$ group to 0 group sandeels, while effects in subsequent years accrue through the overall reduction in the abundance of older sandeels. In addition, the abundance of 0 group sandeels may be affected in subsequent years if fishing reduces the spawning stock to the point where egg production limits the numbers of 0 group fish. Alternatively, density dependence may be occurring, since in the southwestern and northeastern North Sea, abundances of 1 group and 0 group sandeels are negatively correlated (Arnott and Ruxton 2002). If so, a fishery could potentially have a beneficial effect on seabirds for which 0 group sandeels are important. Furthermore, there is likely to be a lack of generality among seabird species of fishery effects because of differences in foraging ecology. Furness and Tasker (2000) presented a sensitivity index of breeding success to sandeel abundance of North Sea seabirds that was determined by multiplying proportion of sandeel in the diet by a "vulnerability of breeding success to reduced abundance of food" score based on six variables (body size, cost of foraging, foraging range, ability to dive, amount of spare time in daily budget, and ability to switch prey). Their study showed a broad range of sensitivity of breeding success to sandeel abundance across seabird species. Thus, the interrelationship among the fishery, sandeels, and seabirds is complex.

An industrial fishery for sandeels began on the sandbanks of the Wee Bankie, Marr Bank, and Berwick's Bank $40 \mathrm{~km}$ off the coast of southeast Scotland in 1990 and continued until 1999. This area is used extensively by sandeel-specialist seabirds from April until August (Wanless et al. 1998; Daunt et al. 2002; Camphuysen 2005). A bioenergetics model of the prey consumption of seabirds foraging in this area in 1997 revealed that they consumed large numbers of 0 group and in particular 1+ group sandeels (Wanless et al. 1998). One seabird species, the black-legged kittiwake (Rissa tridactyla), had exhibited marked declines in breeding performance and population size while the fishery was operating (Frederiksen et al. 2004). The breeding success of this species, considered to be particularly sensitive to fluctuation in sandeel abundance (Furness and Tasker 2000), was selected as an indicator of sandeel abundance (ICES 1999; 2001). Concerns were raised regarding the potential negative impact of the Wee Bankie sandeel fishery on predators, and an area off the east coast of Scotland, including the Wee Bankie complex, was closed to commercial fishing in 2000 (European Commission 2000; Wright et al. 2002; Fig. 1). A small monitoring fishery has occurred each year since closure.

The juxtaposition of fishery and non-fishery years spanning a continuous period (1996-2003) during which demographic and diet data for the full range of sandeel-specialist seabird predators in the study area and estimates of sandeel abundance for 7 of the 8 years are available (Greenstreet et al. 2006) provides a unique opportunity to assess the effectiveness of fishery closure as a management tool for improving the performance of top predators. This paper has three aims. First, estimate monthly consumption of sandeels by seabirds associated with breeding colonies in the area, from April to August in each of the 8 years, using a bioenergetics modelling approach (Furness 1982). Second, quantify the temporal and spatial overlap between the consumption of sandeels by seabirds and the removal of sandeels by the fishery. Third, evaluate whether fishery closure has increased consumption rates of sandeels by seabirds, proportion of seabirds using the area where the fishery had taken place, and seabird breeding success. We predicted that there would be a more positive impact of fishery closure on the performance of species that are more sensitive to changes in sandeel abundance (notably, the black-legged kittiwake) based on Furness and Tasker's sensitivity index (Furness and Tasker 2000) recalculated with our data on sandeel proportion in the diet.

\section{Materials and methods}

\section{Study area and species}

The area in which seabird distributions were determined was bounded by $56^{\circ} 00^{\prime} \mathrm{N}$ to the south, $56^{\circ} 30^{\prime} \mathrm{N}$ to north, $3^{\circ} 00^{\prime} \mathrm{W}$ to the west, and $1^{\circ} 00^{\prime} \mathrm{W}$ to the east (ICES boxes $41 \mathrm{E} 7$ and 41E8, hereafter referred to as the study area; see Fig. 1). The seabird species for which we had sufficient data to include in the model, with the index of sensitivity of breeding success to sandeel abundance presented in Furness and Tasker (2000) given after each species (higher values indicating greater sensitivity), were as follows: European shag, Phalacrocorax aristotelis (shag, 8); northern gannet, Morus bassanus (gannet, 1); black-legged kittiwake, (kittiwake, 10); common guillemot, Uria aalge (guillemot, 5); razorbill, Alca torda (7); Atlantic puffin, Fratercula arctica (puffin, 8); common tern, Sterna hirundo (8); arctic tern, Sterna paradisaea (13); roseate tern, Sterna dougallii (7); and sandwich tern, Sterna sandvicensis (11). The four tern species were combined in the bioenergetics model because of low population sizes and lack of data on interspecific variation in diet. Northern fulmar (Fulmarus glacialis), great cormorant (Phalacrocorax carbo), great black-backed gull (Larus marinus), 
Fig. 1. Map showing the location of 18 International Council for the Exploration of the Sea (ICES) rectangles for which Danish sandeel fishery catch data were examined. The three shades of grey represent (from darkest to lightest): $(a)$ the study area (ICES rectangles 41E7 and 41E8) in which seabird and sandeel surveys were made; (b) the seven rectangles that, together with 41E7 and 41E8, were closed to sandeel fishermen from 2000 (the remaining closed area); $(c)$ the nine rectangles east of the closed area (the open area). The at-sea seabird and acoustic survey transects (broken line) and demersal trawl stations (solid circles) are shown. The source colonies of birds that were predominantly feeding in the study area are shown as white squares, including the two colonies that provided data on breeding success (IM, Isle of May; SA, St Abbs).

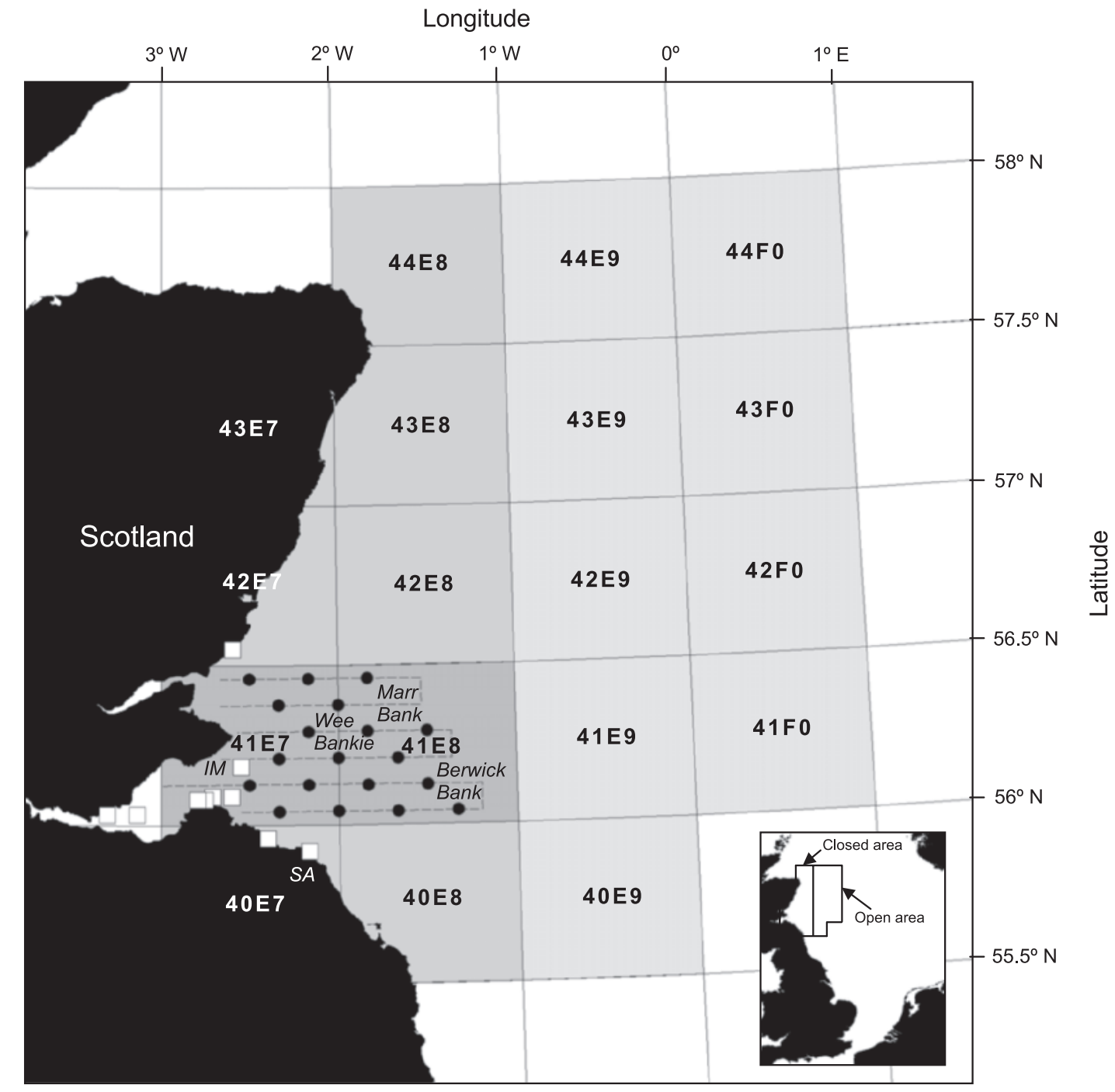

lesser black-backed gull (Larus fuscus), and herring gull (Larus argentatus) also breed in the area. The former is dependent on pelagic prey, and the latter four depend largely on freshwater environments, terrestrial environments, and (or) non-fish vertebrate prey. However, they do consume some sandeels, but are excluded, since detailed diet data were lacking. Accordingly, our consumption estimates by the seabird population as a whole are underestimated.

Foraging locations from at-sea surveys (Wanless et al. 1998; Camphuysen 2005) and from breeding birds carrying transmitting devices (Wanless et al. 1990, 1991; Hamer et al. 2000) or archival loggers (Daunt et al. 2002, 2006; Wanless et al. 2005) indicated that the source colonies of birds that foraged in the study area came from the east coast of Scotland and northern England from the Angus coast to St Abbs Head (Fig. 1).

The other seven ICES boxes that were closed to fishing from 2000 are shown (the remaining closed area; together with study area referred to as closed area), as well as the nine ICES boxes to the east of the closed area that were open throughout the study period (open area; Fig. 1).

\section{Sandeel consumption}

Sandeel consumption by seabirds was estimated from 1996 to 2003 for each month from April to August inclusive and for each age class. Detailed methods and results of input 
parameters are described in Appendix A and Appendix B, respectively. Consumption (in tonnes, t) by breeding adults was given by

$$
\text { Consumption }(\mathrm{t})=\{[(n \cdot a \cdot d) / e] b\} /\left(c \times 10^{6}\right)
$$

where $n$ is the number of individuals, $a$ is presence in the study area (days), $d$ is daily energy expenditure (DEE, in $\mathrm{kJ}), e$ is assimilation efficiency, $b$ is biomass proportion in diet, and $c$ is energy density of prey $\left(\mathrm{kJ} \cdot \mathrm{g}^{-1}\right)$. For nonbreeders, the following equation was used:

$$
\text { Consumption }(\mathrm{t})=\{[(n \cdot i \cdot a \cdot d) / e] b\} /\left(c \times 10^{6}\right)
$$

where $i$ is the number of immature birds, expressed as a proportion of the breeding adult population derived from a simple population model (Appendix A). For chicks, consumption was given by

$$
\text { Consumption }(\mathrm{t})=\{[(p \cdot s \cdot a \cdot d) / e] b\} /\left(c \times 10^{6}\right)
$$

where $p$ is the number of pairs and $s$ is breeding success (chicks fledged per pair). A total of 1680 calculations were made (two sandeel age classes; seabird adults, immature birds, chicks; seven species, eight years, five months per year).

\section{At-sea distributions}

\section{At-sea surveys}

Seabirds were surveyed at sea from the FRV Clupea on 21-25 June 1997, 13-16 June 1998, 2-5 July 1999, 14-19 June 2000, 4-9 June 2001, 15-19 June 2002, and 14-17 June 2003. The difference in dates among years should not have biased among-year differences, since there is no evidence that numbers present in the study area vary between early June and early July in any of the study species. Each survey consisted of six transects steamed in an east-west direction (Fig. 1), generally following methods in Tasker et al. (1984) and Webb and Durink (1992). Transects were $300 \mathrm{~m}$ wide to one side of the vessel, and numbers of birds on the water and in flight were aggregated into 5 min survey periods from which densities in $5^{\prime}$ latitude $\times 10^{\prime}$ longitude subareas (equivalent to approximately seven 5 min periods) were estimated. Summing abundance over all subareas provided estimates of the observed numbers present in the study area (full details in Wanless et al. 1998).

\section{Expected at-sea populations}

For all species, both parents share incubation and chickrearing duties. It was assumed that $50 \%$ of breeding adult gannets, kittiwakes, guillemots, razorbills, and terns were foraging at any one time in all years of the study (Harris and Wanless 1997; Lewis et al. 2004). Breeding shags spend approximately $30 \%$ of the daylight period at sea (Enstipp et al. 2006). In contrast, breeding puffins spend the majority of time at sea, and a value of $80 \%$ was used (Wanless et al. 1998). Nonbreeding, immature birds spend some time at the colony during the prospecting and recruitment phases, so $80 \%$ of birds in this category were assumed to be at sea at any one time ( $50 \%$ for shags). We were therefore able to estimate the expected numbers of each species in the study area at any particular time. The proportion of observed to expected was used as a measure of the proportion of the population present in the study area.

\section{Breeding success}

Breeding success (i.e., the number of chicks fledged per breeding pair) was available for shag, kittiwake, guillemot, razorbill, puffin, common tern, and arctic tern in all years (see Appendix A). Shag and kittiwake breeding success was available at two separate colonies (Isle of May and St Abbs). Common and arctic tern breeding success was a combined estimate, because when breeding together, the young of these two species cannot easily be separated. Insufficient data were available to assess changes in breeding success of gannet, sandwich tern, or roseate tern.

\section{Fishery landings}

Weekly landings from March to October 1996-1999 by the industrial fishery and from March to October 2000-2003 by the monitoring fishery were taken from Danish fishery logbook data (Dalskov 2002; ICES 2006), which are stored in the Logbook Database in the Danish Directorate for Fisheries (Dalskov 2002). Landings correspond very closely to catches, with independent observers on fishing vessels estimating that underreporting in weight is of the order of $5 \%-$ $10 \%$. Landings for the study area, the remaining closed area, and the open area were available throughout this period.

\section{Sandeel abundance}

Abundance of 0 group and 1+ group sandeels in the study area were derived from FRV Clupea acoustic surveys (same dates and transects as seabird surveys) and demersal trawls (27 June - 3 July 1997, 18-22 June 1998, 7-11 July 1999, 20-24 June 2000, 30 May - 3 June 2001, 9-13 June 2002, and 6-11 June 2003; see Fig. 1 for location of transects and trawl stations). Full details of how annual abundance of each age class from 1997 to 2003 were derived are given in Greenstreet et al. (2006). Briefly, acoustic surveys assess the abundance of sandeels in the water column, and demersal trawls assess sandeels buried in the sediment. The proportion of the sandeel population in each habitat varies with time of year and age class, and since the timing of cruises varied between years, the two estimates are uncorrelated across years. Greenstreet et al. (2006) utilized data from the two surveys to estimate total sandeel abundance of each age class, using a model that corrected the relative abundance of sandeels in each habitat for the timing of the cruise in relation to the timing of the spring bloom (a key determinant of sandeel behaviour (Scott et al. 2006) and calculated by a onedimensional, coupled, bio-physical model (Sharples et al. 2006)). The model was validated with sandeel abundance estimates from day-grab surveys of sandeels buried in the sediment carried out in the autumn (Holland et al. 2005), when all sandeels are in the substrate (Greenstreet et al. 2006).

\section{Statistical analyses}

Each calculation of food consumption was achieved by Monte Carlo simulation, repeated 10000 times, using randomly selected values from specified distributions of the input variables. For normally distributed data (e.g., population size, DEE), we used standard deviations, with the exception of energy density of fish (standard errors). For data bounded in both directions (e.g., assimilation efficiency, biomass proportions), we used binomial standard errors with a beta distribution. Where more than one estimate was available for 
the same parameter (see Appendix A), weighted means based on population size at each location were used, and error estimation followed the rule $\operatorname{var}(x+y)=\operatorname{var}(x)+\operatorname{var}(y)$. Where error estimates were not available, a value of $\pm 20 \%$ was used. Means and standard deviations were calculated for each month, year, and species, and the values were summed to generate annual and monthly summaries for each species and for all species combined. To test the sensitivity of the model to parameter error, we examined separate parameters by holding the values of all other parameters at their mean. This was only possible with those variables with true error estimates for all species, namely breeding success, diet composition, and DEE.

We compared consumption, proportion of the population utilizing the study area, and breeding success with the abundances of 0 group and 1+ group using Spearman's coefficient of rank correlations $\left(r_{\mathrm{S}}\right)$. As consumption is a direct function of population size, we carried out analyses on consumption rates (i.e., total consumption/population size). Separate analyses were carried out on consumption rates of 0 group and 1+ group sandeels for each seabird species separately, for the overall population (4 years only, because gannet diet was sampled in 4 years; Appendix A), and for the overall population excluding the gannet (all years). Analyses of the proportion of birds in the study area, using the same approach, were carried out on all species except shags and terns (whose distribution at sea is poorly estimated; see Discussion) and on the population as a whole (including gannets). Analyses on breeding success were carried out on all species except gannets, sandwich terns, and roseate terns.

\section{Results}

\section{Sensitivity to sandeel abundance}

Furness and Tasker's index of sensitivity of breeding success to sandeel abundance (Furness and Tasker 2000) was recalculated with our data on sandeel proportion in the diet (Table 1). We found that the black-legged kittiwake are most sensitive to variation in sandeel abundance, followed by puffins and razorbills. Shags, guillemots, and terns show intermediate sensitivities, and gannets are the least sensitive.

\section{Sandeel consumption}

$1+$ group sandeels were consumed in greater quantities than 0 group by shags and guillemots; the converse was true for gannets; and both age classes were equally important in the diet of the remaining species (Fig. 2). Gannets were the main sandeel consumer because of their high population size, body mass, and DEE. Guillemots and puffins consumed similar quantities, followed by kittiwakes, razorbills, shags, and terns. Total consumption of sandeels by the seven species combined increased from $16617 \pm 5860 \mathrm{t}$ in 1996 to $24474 \pm 7436 \mathrm{t}$ in 2003 , with a peak of $27894 \pm 8510 \mathrm{t}$ in 2002 (Fig. 2), largely because of population increases in gannets, guillemots, and puffins during the study period (Appendix B).

There was a strong seasonal pattern in age class of sandeels eaten in three of the four species where there were sufficient data to look for seasonal trends (gannet, kittiwake, and guillemot; Fig. 3). The same pattern probably holds for razorbill and puffin (Wanless et al. 2004). Only shag main-
Table 1. Index of sensitivity of breeding success to sandeel abundance of the seven study species (after Furness and Tasker 2000).

\begin{tabular}{llll}
\hline & $\begin{array}{l}\text { Vulnerability } \\
\text { score }\end{array}$ & $\begin{array}{l}\text { Proportion of } \\
\text { sandeels in diet }\end{array}$ & $\begin{array}{l}\text { Sensitivity to } \\
\text { sandeel abundance }\end{array}$ \\
\hline Kittiwake & 16 & 0.87 & 13.9 \\
Puffin & 13 & 0.81 & 10.5 \\
Razorbill & 12 & 0.77 & 9.2 \\
Shag & 8 & 0.96 & 7.7 \\
Guillemot & 9 & 0.84 & 7.6 \\
Tern spp. & 21.8 & 0.34 & 7.4 \\
Gannet & 5 & 0.42 & 2.1 \\
\hline
\end{tabular}

Note: The index is obtained by multiplying the vulnerability score taken from Furness and Tasker (2000) (i.e., the vulnerability of breeding success to reduced food abundance, based on body size, cost of foraging, foraging range, ability to dive, amount of spare time in daily budget, and ability to switch diet; the score for terns is a corrected value based on mean relative population size across years) by the proportion of sandeels in the diet, using data from this study (mean across years). The sandeel proportion for guillemots is a value corrected for mean energetic requirements of the two age classes.

tained a high consumption of $1+$ sandeels throughout the season. The seasonal pattern across the species combined demonstrated a strong overall shift in consumption from 1+ group sandeels in April and May to primarily 0 group sandeels from June onwards (Fig. 3).

The model was most sensitive to estimates of diet composition $($ coefficient of variation $(\mathrm{CV})=0.11-0.27$, mean $=$ $0.17)$, followed by DEE $(\mathrm{CV}=0.11-0.13$, mean $=0.12)$. Errors associated with breeding success data had a very small impact on consumption estimation $(\mathrm{CV}=0.006-0.007$, mean $=0.006)$.

\section{At-sea distributions}

The estimated at-sea populations and expected numbers derived from individuals in the study area are provided in Table 2. There was considerable variation between years, but some consistent patterns among species. The number of guillemots observed at sea accorded well with expected values (mean proportion $=0.87$ across 7 years; Table 2 ), and guillemot was the only species in which observed numbers were higher than those expected in 1 year. For the other species, observed numbers were consistently lower than expected (Table 2).

\section{Fishery landings}

Annual landings in the 18 ICES rectangles were highest in 1996 and lowest in 2002, but otherwise were comparatively stable at $\sim 50000 \mathrm{t}$ (Fig. 4). However, there were marked changes in spatial distribution, with higher catches in the closed area in 1996-1998 than in 1999, the last year of industrial fishery, and during the monitoring fishery in 20002003 (Fig. 4). Thus, from 1999 onwards, the fishery shifted offshore. Throughout the study period, and particularly while the monitoring fishery took place, sandeel catches from the closed area primarily occurred in the study area $(67 \%-89 \%$ in the industrial fishery years; $96 \%-99 \%$ in the monitoring fishery years; Fig. 4). Nearly all the sandeels caught from the closed area were taken in June (Fig. 5), with the exception of 1999, when a greater proportion was caught in March and May. This pattern was particularly apparent 
Fig. 2. Total consumption of $1+$ group sandeels (open bars), 0 group sandeels (solid bars), and both age groups combined (shaded bars) for each species and all species combined from 1996 to 2003 (mean + standard deviation). Years with no consumption (see Appendix A for details) are missing data. Species are as follows: shag (European shag, Phalacrocorax aristotelis); gannet (northern gannet, Morus bassanus); kittiwake (black-legged kittiwake, Rissa tridactyla); guillemot (common guillemot, Uria aalge); razorbill (Alca torda); puffin (Atlantic puffin, Fratercula arctica); terns (common tern, Sterna hirundo; arctic tern, Sterna paradisaea; roseate tern, Sterna dougallii; sandwich tern, Sterna sandvicensis).

(a) shag

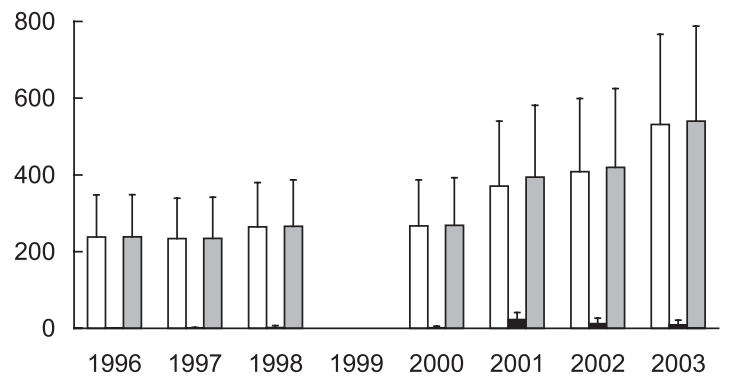

(c) kittiwake

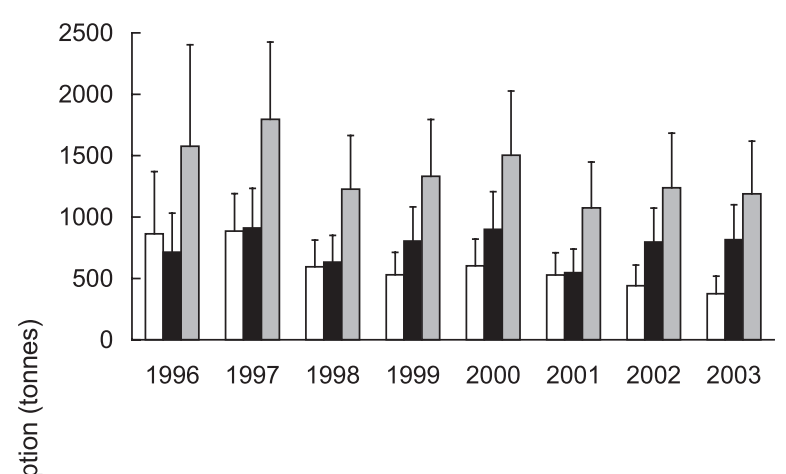

(e) razorbill

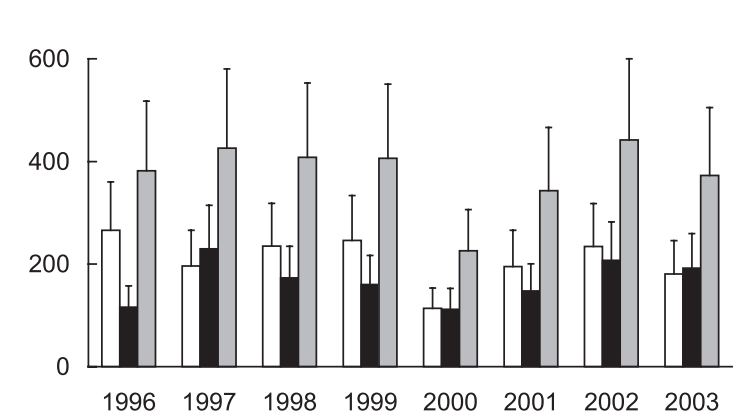

(g) terns

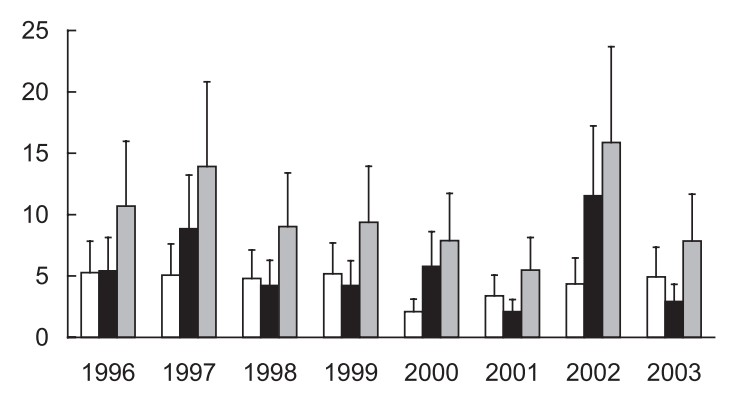

(b) gannet

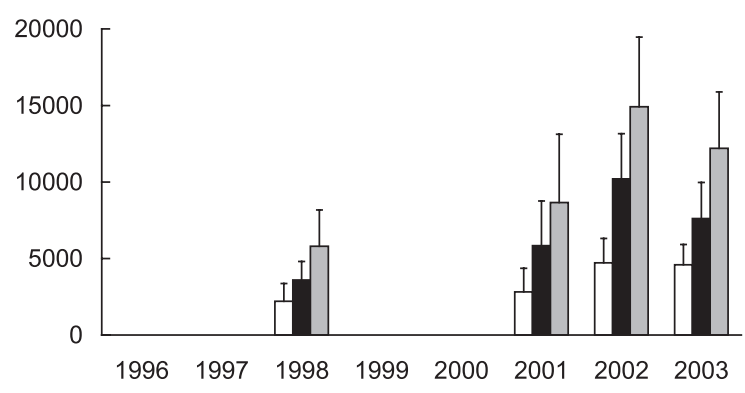

(d) guillemot

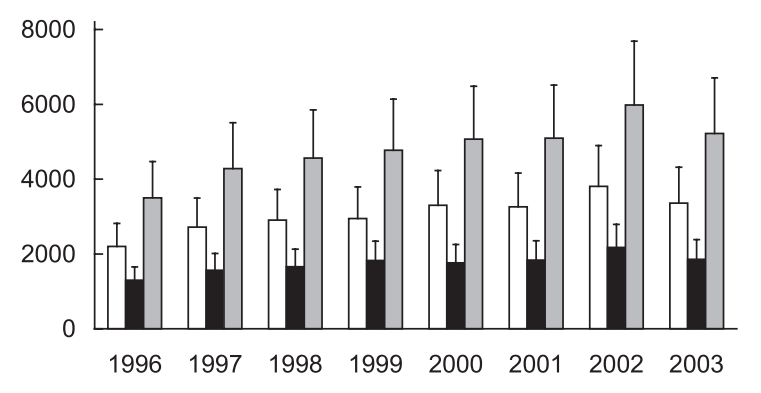

(f) puffin

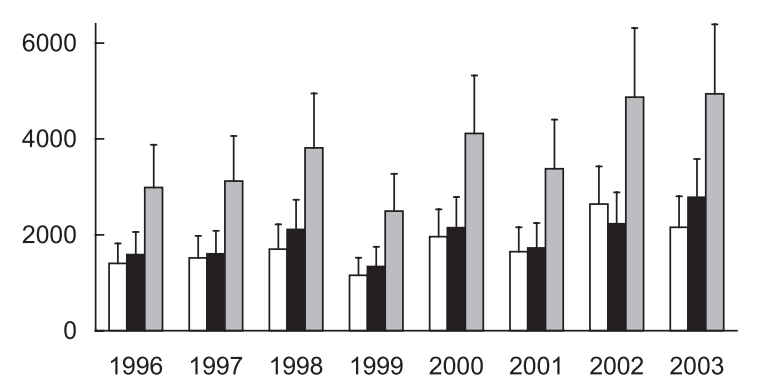

(h) all species

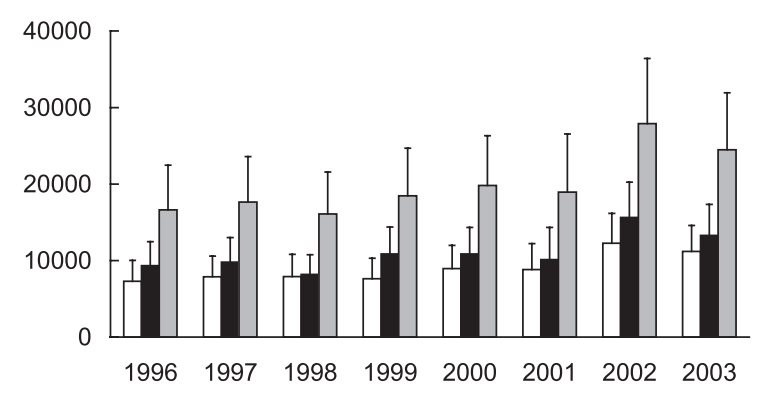


Fig. 3. Monthly consumption of $1+$ group (open bars) and 0 group sandeels (solid bars) by each species and all species combined (mean + standard deviation). For each month, values are means across years. Months where species were not present in the study area (see Appendix A for details) are excluded; months where no consumption is shown are missing data.

$$
\text { (a) shag }
$$

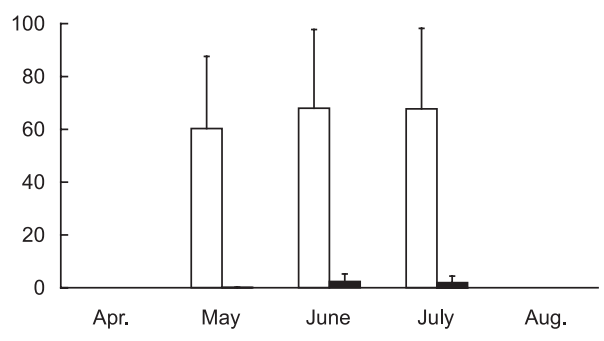

(c) kittiwake

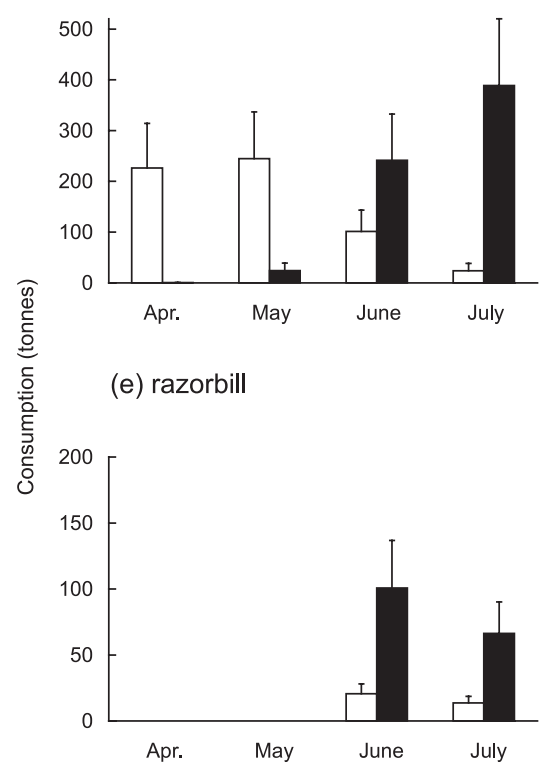

(g) terns

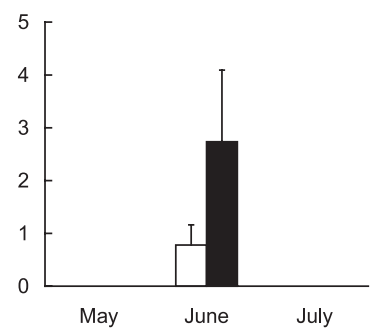

(b) gannet

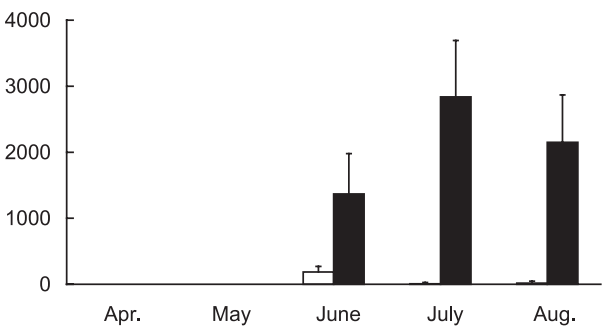

(d) guillemot

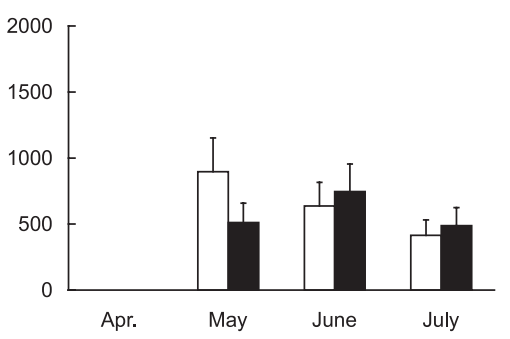

(f) puffin

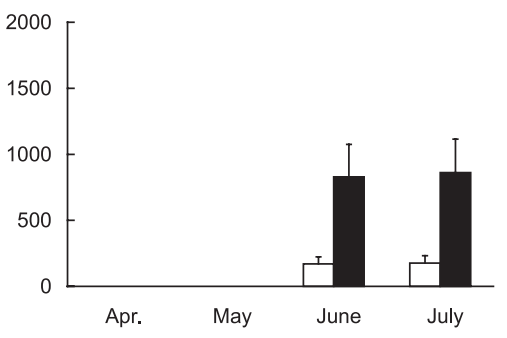

(h) all species

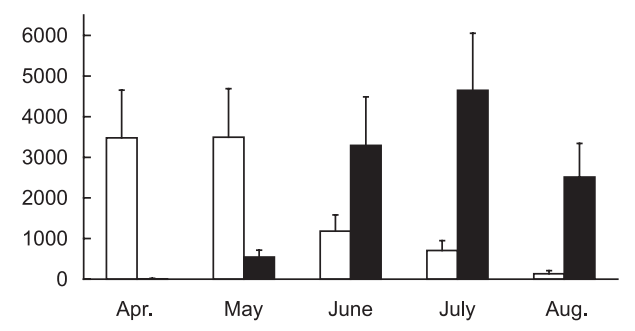

Month

when only the study area was considered. In the open area, the timing of sandeel fishing was more variable and generally started earlier (Fig. 5).

\section{Sandeel abundance}

There was an increase in the abundance of both 0 group and 1+ group sandeels from a combined total of $\sim 50000 \mathrm{t}$ in 1997 to $2350000 \mathrm{t}$ in 2003, with a peak of $>400000 \mathrm{t}$ in 2000 and 2001 (Fig. 6). The biomass of both age classes increased between 1999 and 2000, and for 1+ group the bio- mass in each of the 4 years of closure exceeded the biomass in all three of the fishery years. With the exception of 1999, when the week of maximum landings occurred 6 weeks prior to the surveys, the surveys took place within a week of maximum landings. Thus, it was impossible to know if abundance estimates reflected before or after fishery levels.

\section{Sandeel abundance and seabird performance}

For the seabird population as a whole, there was a tendency for 0 group sandeel abundance to have an effect on 
Table 2. Observed, expected, and proportion of observed to expected numbers of individuals present in the study area.

\begin{tabular}{|c|c|c|c|c|c|c|c|c|}
\hline Year & Shag & Gannet & Kittiwake & Guillemot & Razorbill & Puffin & Tern spp. & Total \\
\hline \multicolumn{9}{|c|}{ Observed } \\
\hline 1997 & 249 & 19431 & 13898 & 53352 & 2455 & 26167 & 475 & 116027 \\
\hline 1998 & 441 & 39982 & 16755 & 53642 & 2089 & 34285 & 273 & 147467 \\
\hline 1999 & 158 & 16405 & 7514 & 49425 & 4636 & 24261 & 0 & 102399 \\
\hline 2000 & 23 & 33339 & 16892 & 45040 & 6588 & 38002 & 116 & 140000 \\
\hline 2001 & 395 & 19714 & 14490 & 44353 & 4369 & 24761 & 197 & 108279 \\
\hline 2002 & 119 & 27934 & 20023 & 76585 & 4111 & 38545 & 97 & 167414 \\
\hline 2003 & 134 & 29229 & 18661 & 83002 & 2705 & 41798 & 280 & 175809 \\
\hline \multicolumn{9}{|c|}{ Expected } \\
\hline 1997 & 1172 & 58679 & 42738 & 62993 & 8330 & 115947 & 2362 & 292221 \\
\hline 1998 & 1219 & 60008 & 29737 & 59956 & 8591 & 126818 & 1850 & 288179 \\
\hline 1999 & 825 & 61369 & 28984 & 62843 & 9142 & 143027 & 2687 & 308877 \\
\hline 2000 & 1350 & 62759 & 32381 & 69899 & 8729 & 137306 & 3171 & 315595 \\
\hline 2001 & 1729 & 64180 & 24111 & 66519 & 8755 & 141120 & 2985 & 309399 \\
\hline 2002 & 1778 & 65635 & 25991 & 77719 & 8673 & 149893 & 1364 & 331053 \\
\hline 2003 & 2273 & 67123 & 21777 & 66800 & 6958 & 160382 & 2367 & 327680 \\
\hline \multicolumn{9}{|c|}{ Proportion observed to expected } \\
\hline 1997 & 0.21 & 0.33 & 0.33 & 0.85 & 0.29 & 0.23 & 0.2 & 0.4 \\
\hline 1998 & 0.36 & 0.67 & 0.56 & 0.89 & 0.24 & 0.27 & 0.15 & 0.51 \\
\hline 1999 & 0.19 & 0.27 & 0.26 & 0.79 & 0.51 & 0.17 & 0 & 0.33 \\
\hline 2000 & 0.02 & 0.53 & 0.52 & 0.64 & 0.75 & 0.28 & 0.04 & 0.44 \\
\hline 2001 & 0.23 & 0.31 & 0.6 & 0.67 & 0.5 & 0.18 & 0.07 & 0.35 \\
\hline 2002 & 0.07 & 0.43 & 0.77 & 0.99 & 0.47 & 0.26 & 0.07 & 0.51 \\
\hline 2003 & 0.06 & 0.44 & 0.86 & 1.24 & 0.39 & 0.26 & 0.12 & 0.54 \\
\hline Mean & 0.16 & 0.42 & 0.56 & 0.87 & 0.45 & 0.23 & 0.09 & 0.44 \\
\hline SD & 0.12 & 0.14 & 0.22 & 0.21 & 0.17 & 0.04 & 0.07 & 0.08 \\
\hline
\end{tabular}

Fig. 4. Annual sandeel catches taken from the study area (black shading), the remaining closed area (dark grey shading), and the open area (light grey shading).

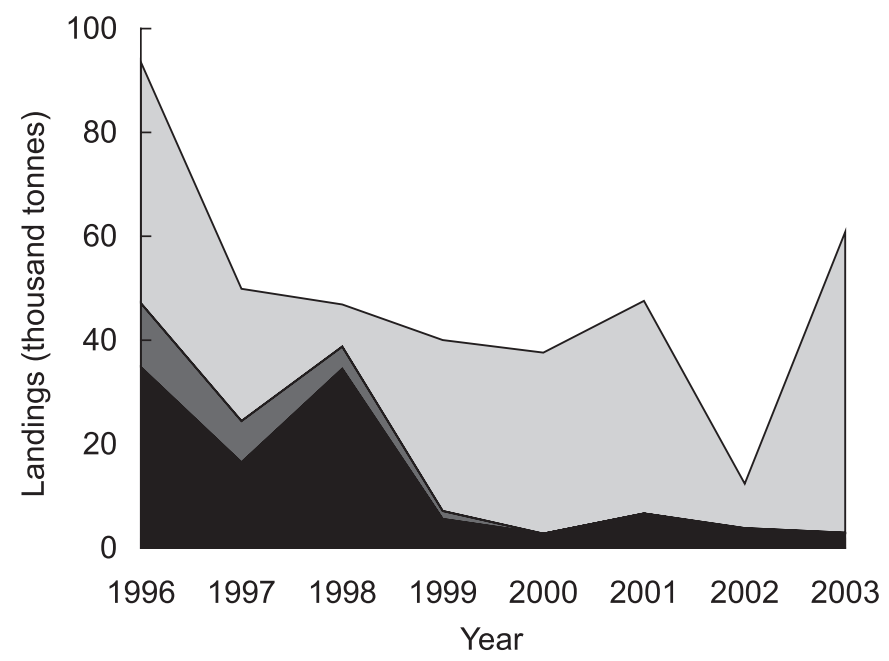

0 group consumption rates $\left(7\right.$ years excluding gannets: $r_{\mathrm{S}}=$ $0.64, P=0.12$; 4 years, all species: $\left.r_{\mathrm{S}}=0.60, P=0.40\right)$, but abundance of $1+$ group sandeels did not affect $1+$ group consumption rates ( 7 years excluding gannets: $r_{\mathrm{S}}=0.25, P=$ 0.59 ; 4 years, all species: $\left.r_{\mathrm{S}}=0.20, P=0.80\right)$. However, there was a positive relationship between 0 group sandeel abundance and 0 group consumption rates for kittiwakes (Fig. 7a), and the suggestion of a similar relationship in gannets $\left(r_{\mathrm{S}}=0.80, P=0.20\right)$. For none of the other species was consumption of either age class of sandeels associated with sandeel abundance (0 group: shag, $r_{\mathrm{S}}=0.09, P=0.87$; guillemot, $r_{\mathrm{S}}=0.04, P=0.94$; razorbill, $r_{\mathrm{S}}=0.32, P=0.48$; puffin, $r_{\mathrm{S}}=0.43, P=0.34$; terns, $r_{\mathrm{S}}=0.04, P=0.94 ; 1+$ group: shag, $r_{\mathrm{S}}=-0.20, P=0.80$; gannet, $r_{\mathrm{S}}=0.20, P=$ 0.80 ; kittiwake, $r_{\mathrm{S}}=-0.11, P=0.82$; guillemot, $r_{\mathrm{S}}=-0.46$, $P=0.29$; razorbill, $r_{\mathrm{S}}=-0.61, P=0.15$; puffin, $r_{\mathrm{S}}=0.32$, $P=0.48$; terns, $\left.r_{\mathrm{S}}=-0.54, P=0.22\right)$.

There was no effect of 0 group or $1+$ group abundance on the proportion of the total seabird population utilizing the study area (0 group: $r_{\mathrm{S}}=0.56, P=0.19 ; 1+$ group: $r_{\mathrm{S}}=0.07$, $P=0.88$ ). When considering species separately, there was a tendency for the proportion of kittiwakes utilizing the study area to be positively related to the abundance of 0 group sandeels (Fig. 7b). There was also a tendency for a positive relationship between razobills and the abundance of 1+ group, and the proportion of gannets in the study area was positively related to 0 group abundance, except in 1998 when higher numbers were present than would have been predicted from 0 group abundance ( 0 group: gannet, $r_{\mathrm{S}}=0.14, P=0.76$; guillemot, $r_{\mathrm{S}}=0.39, P=0.38$; razorbill, $r_{\mathrm{S}}=0.14, P=0.76$; puffin, $r_{\mathrm{S}}=0.27, P=0.56$; $1+$ group: gannet, $r_{\mathrm{S}}=0.10, P=$ 0.82 ; guillemot, $r_{\mathrm{S}}=-0.39, P=0.38$; razorbill, $r_{\mathrm{S}}=0.71, P=$ 0.07 ; puffin, $r_{\mathrm{S}}=0.27, P=0.56$ ).

Kittiwake breeding success was positively related to the abundance of both 0 group and 1+ group sandeels; the relationships were significant for one (the Isle of May) of the two colonies where breeding success was measured (Figs. $7 c, 7 d$; St Abbs: 0 group, $r_{\mathrm{S}}=0.60, P=0.15 ; 1+$ 
Fig. 5. Monthly sandeel catches in each year in the study area, the remaining closed area, and the open area.

Study area
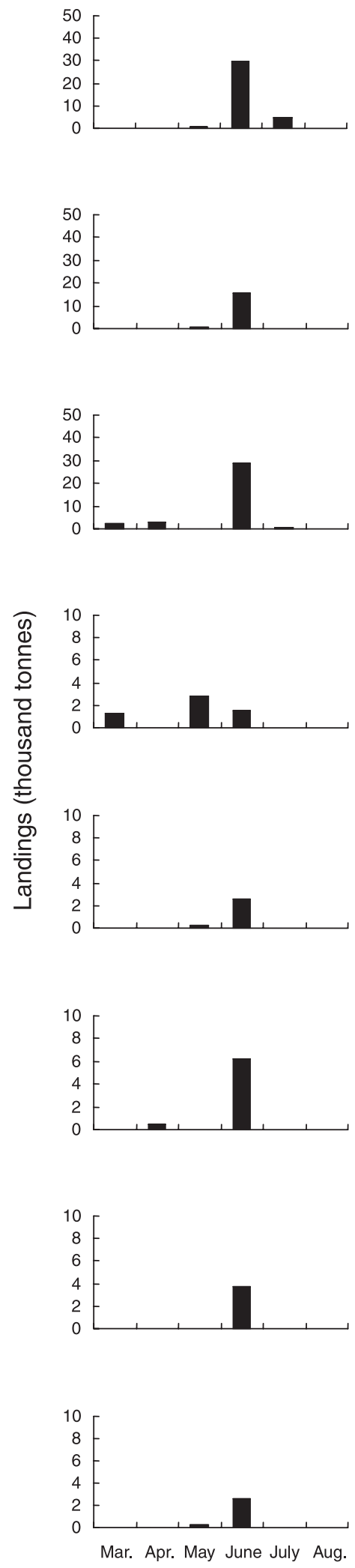

Remaining closed area
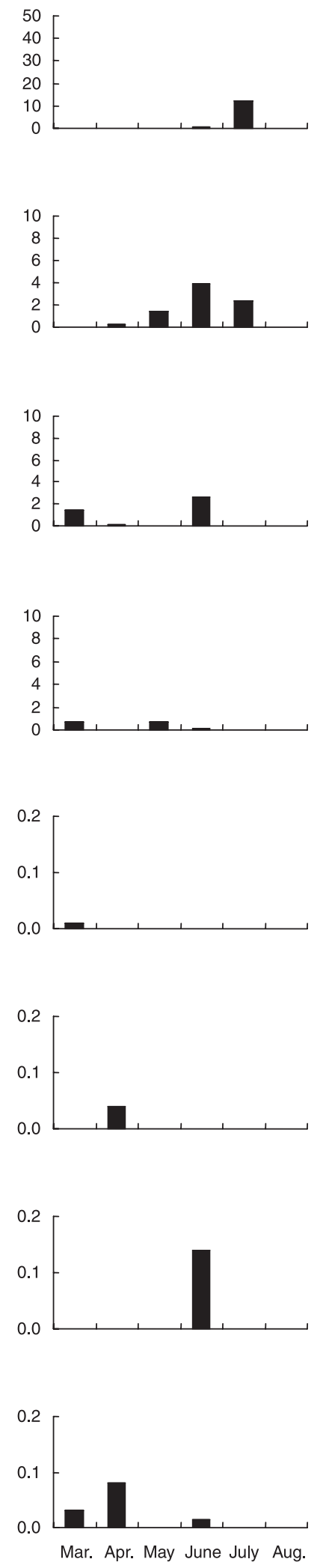

Month
Open area
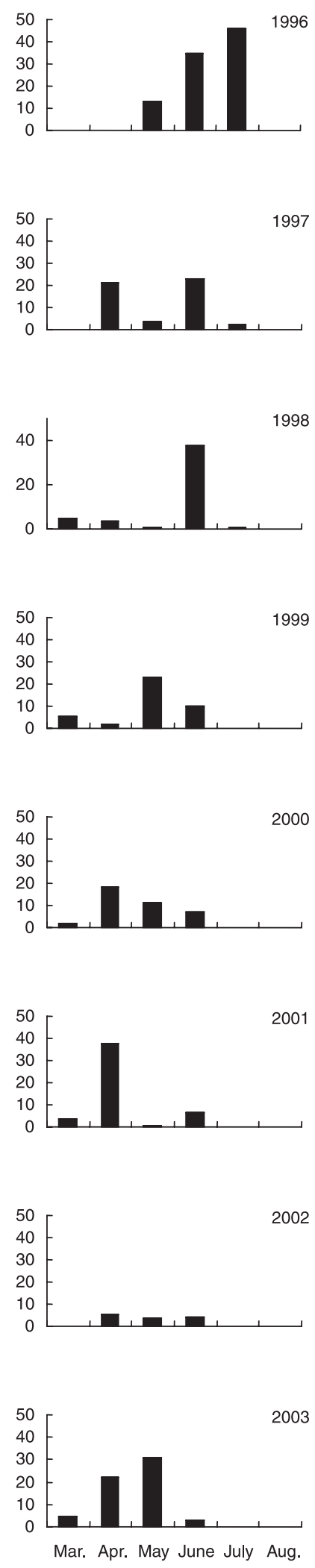
Fig. 6. Abundance (t) of 1+ group (open bars) and 0 group (solid bars) sandeels in June 1997-2003 in the study area (estimated by Greenstreet et al. 2006).

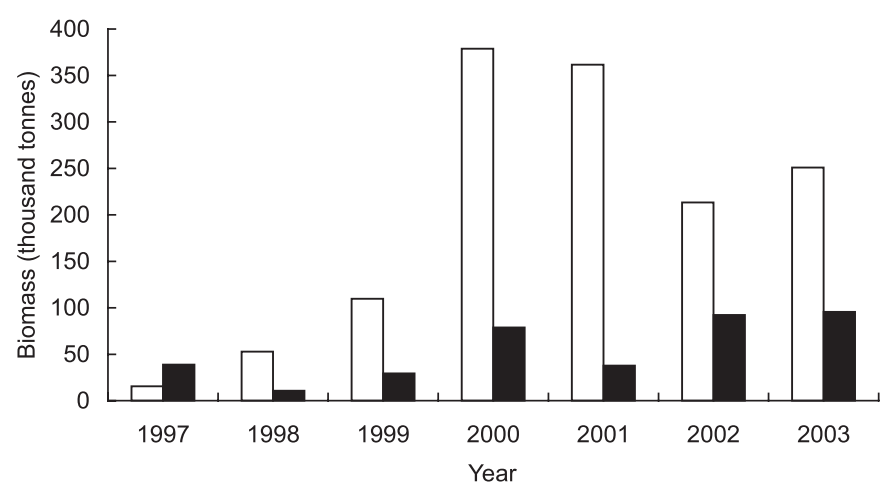

group, $\left.r_{\mathrm{S}}=0.36, P=0.43\right)$. There was a tendency for shag breeding success to be related to abundance of both 0 group and 1+ group sandeels, but the breeding success of guillemot, razorbill, puffin, common tern, and arctic tern was unrelated to the abundance of either sandeel age class ( 0 group: shags on Isle of May, $r_{\mathrm{S}}=0.68, P=0.09$; shags at St Abbs, $r_{\mathrm{S}}=$ $0.68, P=0.09$; guillemot, $r_{\mathrm{S}}=0.06, P=0.91$; razorbill, $r_{\mathrm{S}}=$ $0.41, P=0.36$; puffin, $r_{\mathrm{S}}=0.14, P=0.76$; terns, $r_{\mathrm{S}}=-0.29$, $P=0.54 ; 1+$ group: shags on Isle of May, $r_{\mathrm{S}}=0.54$, $P=0.22$; shags at St Abbs, $r_{\mathrm{S}}=0.64, P=0.12$; guillemot, $r_{s}=-0.44, P=0.33$; razorbill, $r_{\mathrm{S}}=0.14, P=0.76$; puffin, $r_{\mathrm{S}}=0.54, P=0.22$; terns, $\left.r_{\mathrm{S}}=-0.04, P=0.94\right)$.

\section{Discussion}

\section{Sandeel consumption model}

This model represents the most detailed consumption estimation of North Sea seabirds to date and a marked improvement in accuracy over the previous model of the study area (Wanless et al. 1998) because of better data on diet and the immature component of the population. These improvements reveal that 0 group consumption by gannets and guillemots is considerably higher than previously thought (Wanless et al. 1998). The model underestimates total consumption because we lacked detailed data for northern fulmar, great cormorant, great black-backed gull, lesser black-backed gull, and herring gull. However, based on field observations of food regurgitated to chicks (handled for ringing) that suggest an estimate of 5\%-10\% sandeels in the diet of these species, consumption consists of 145-290 t.year ${ }^{-1}(\sim 1 \%$ of total seabird consumption), so our underestimate is small. Additional data are required on the diet of gannets, because they are potentially the largest consumers of sandeels. Furthermore, more data are required on adult diet in general, because it may differ from chick diet in particular between the auks (Alcidae) and terns, which carry food in their bills (Wilson et al. 2004). Another potential source of error lies in the estimates of DEE, which in many cases are based on small sample sizes and (or) on captive birds. While estimates of the size of the breeding populations are likely to be robust, the size of the nonbreeding population for all species is less certain. It is unknown how realistic our assumption is that only birds within 2 years of recruitment to the breeding population (see Appendix A) are associated with the study area.

\section{Overlap between seabirds and fishery}

The study area was used extensively by guillemots, gannets, kittiwakes, and razorbills. However, other areas were clearly also important. Razorbills use inshore areas, kittiwakes forage both inshore and offshore, while gannets forage over a wide area offshore (Tasker et al. 1985; Hamer et al. 2000; Camphuysen 2005). Fewer than a quarter of the expected numbers of puffins, shags, and terns were found in the study area. Shags and terns are inshore feeding species, while puffins spend considerable amounts of time in dense rafts off the breeding colonies, and neither inshore areas nor those in close proximity to colonies are well covered by atsea surveys (Wanless et al. 1998). Our at-sea surveys tend to underestimate rather than overestimate numbers, since the way the data are collected results in the greater likelihood of individuals being overlooked than double-counted (Wanless et al. 1998). Thus, the importance of the study area is likely to be greater than indicated by our data. Estimation of the proportion of the population using the study area would be improved by a better understanding of the expected number of birds in the area. For example, the observed estimate for guillemots was higher than the expected in 2003, suggesting an error in the latter. The most likely reasons were that the number of immature guillemots associated with the colony was underestimated or that breeding birds from colonies further afield were utilizing the study area.

The majority of the sandeel catch in the closed area originated from the study area. With the exception of the gannet (Hamer et al. 2000), the potential foraging ranges of the seabirds lie within the closed area and uncategorized inshore areas. Thus, it is likely that the majority of sandeels consumed by these species were taken from the study area, since the inshore areas are small and generally unsuitable for sandeels (Bull et al. 2004). Surveys of gannets carried out annually in July from 1997 to 2003 over the region bounded by $54^{\circ} 00^{\prime} \mathrm{N}$ to the south, $59^{\circ} 00^{\prime} \mathrm{N}$ to north, $3^{\circ} 00^{\prime} \mathrm{W}$ to the west, and $2^{\circ} 00^{\prime} \mathrm{E}$ to the east, an area that approximates closely to the foraging range of gannets from the colony at the Bass Rock (Hamer et al. 2000), established that $65 \%$ of observations of scooping behaviour, a mode of feeding used to capture 0 group sandeels, occurred within the study area (K. Camphuysen, Royal Netherlands Institute for Sea Research, P.O. Box 59, NL-1790 AB Den Burg (Texel), The Netherlands, unpublished data). In addition, the majority of regurgitations containing sandeels were of undigested fish, suggesting that they had been caught near the colony (F. Daunt, personal observation). Thus, gannets appear to obtain most 0 group sandeels in the study area. The available evidence therefore indicates considerable spatial overlap between the industrial fishery and seabird feeding areas.

Despite this spatial overlap, consumption of 1+ group sandeels by seabirds (except shags) and fishery catches were temporally segregated prior to the closure, with most catches taking place in June when most species were foraging primarily on 0 group. After closure, temporal overlap increased markedly with more 1+ group caught between March and May, the period when this age class is important for seabirds. However, the reduction in spatial overlap between 
Fig. 7. Relationship between abundance of 0 group sandeels and $(a)$ total consumption rate of 0 group by kittiwakes $\left(r_{\mathrm{S}}=0.75, P=0.05\right)$; (b) ratio of the kittiwake population in the study area $\left(r_{\mathrm{S}}=0.61, P=0.15\right)$; and $(c)$ kittiwake breeding success on the Isle of May $\left(r_{\mathrm{S}}=0.75\right.$, $P=0.05)$. (d) Relationship between $1+$ group abundance and kittiwake breeding success on the Isle of May $\left(r_{\mathrm{S}}=0.86, P=0.01\right)$.
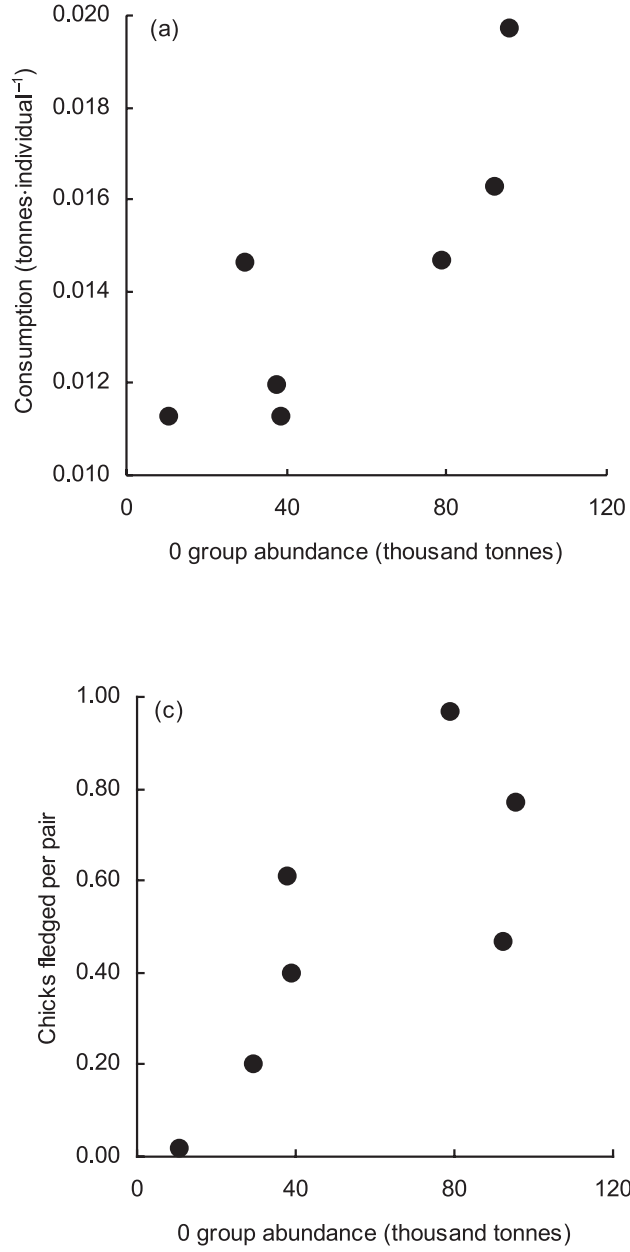

seabird feeding areas and sandeel fishing grounds following closure may have mitigated some of the consequences associated with increased temporal overlap.

\section{Effect of fishery closure on sandeel abundance and seabird performance}

Any effect on seabirds of closing the fishery is likely to have been mediated through an increase in abundance of $1+$ group sandeels resulting from reduced fishing mortality. The abundance of both age classes increased markedly in 2000, the first year of fishery closure (Greenstreet et al. 2006). The large increase in 1+ group sandeel abundance in 2000 was likely to be the combined effects of a substantial decline in fishery removals of sandeels of this age group in 1999 and recruitment of a stronger 0 group cohort in 1999 compared with that in 1998 (Greenstreet et al. 2006). Virtual Population Analysis of the Wee Bankie population is needed to determine the relative contribution of these two processes, but this is not possible because of the relatively short duration of the fishery and a low sampling intensity in the first years of the fishery and during the monitoring fishery. 0 group abundance also increased following closure of the fishery. Although not statistically significant, the biomass of $1+$ and 0 groups were positively related, suggesting that while the
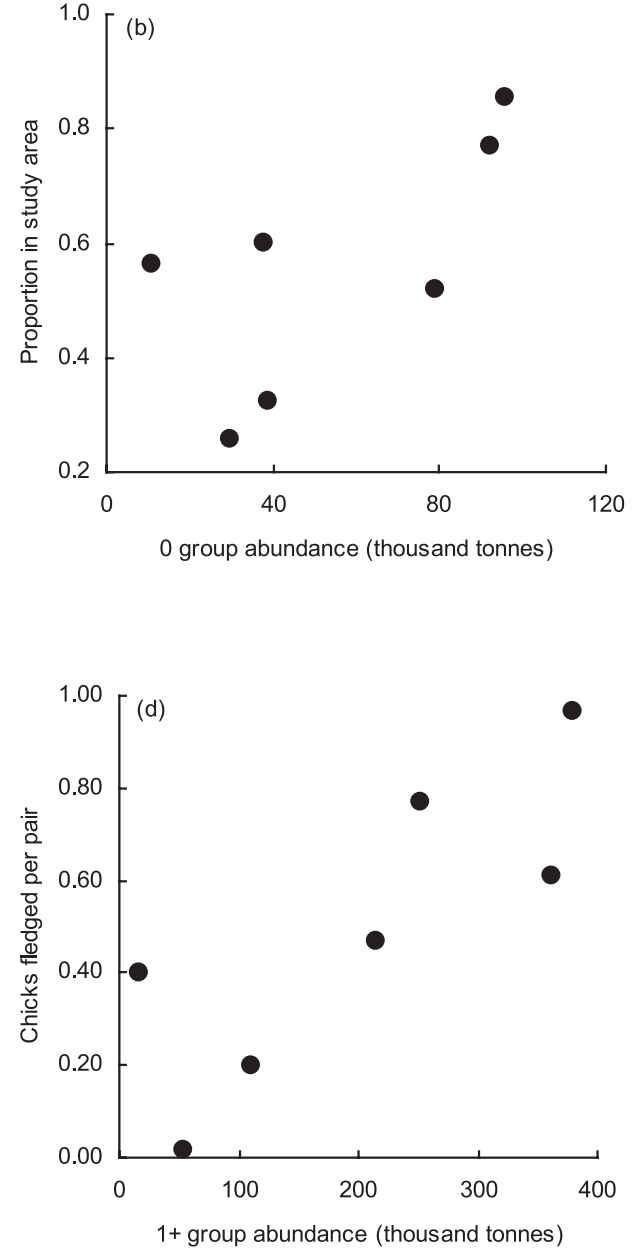

fishery was in operation, exploitation levels may have been sufficiently high to result in recruitment overfishing. However, this possibility is not supported by the local sandeel stock recovering immediately after closure and, despite low $1+$ group abundance in 1998 and 1999, relatively strong 0 group cohorts being produced in 1999 and 2000 (Greenstreet et al. 2006). The increase in 0 group sandeels is more likely because of changes in environmental conditions that have an important impact on survival of the earliest life stages of sandeels (Wright and Bailey 1996), leading to increased survival of larvae from 1999. In Shetland in the early 1990s, improved sandeel recruitment coincided with the closure of the local sandeel fishery, but this was due to oceanographic changes rather than to the closure per se (Wright 1996). An alternative explanation is that natural mortality of 0 group sandeels may have declined over the same period. Although our data suggest that mortality of 0 group sandeels by seabirds has increased, that by piscivorous fish constitutes a considerably greater source of mortality (Furness 2002). From late May onwards, the diet of haddock (Melanogrammus aeglefinus) and whiting (Merlangius merlangus), the two most abundant piscivorous fish in the Wee Bankie area, consists mainly of 0 group sandeels (Greenstreet 2006). Over the study period, the abundance of these two 
species declined substantially, such that the daily consumption rate of 0 group sandeels was reduced by approximately 50\% (Greenstreet 2006).

Our prediction that there would be a lack of generality in the effect of fishery closure across sandeel-specialist seabird species was upheld. On recalculating Furness and Tasker's (2000) sensitivity index of breeding success of North Sea seabirds to sandeel abundance using our diet composition data, we found that kittiwakes were predicted to be the most sensitive. In accordance with this, the performance of kittiwakes was positively correlated with both $1+$ group and 0 group sandeel abundance. Our results support previous studies that demonstrated a relationship between kittiwake breeding success and the abundance and availability of 1+ group (Rindorf et al. 2000; Frederiksen et al. 2004) and 0 group (Harris and Wanless 1997; Lewis et al. 2001) sandeels. Consumption rates of 0 group, but not $1+$ group, sandeels were higher after fishery closure, suggesting that the annual switch from 1+ group to 0 group sandeels occurred earlier in the season. The proportion of the kittiwake population present in the study area also increased. Area usage was more closely related to 0 group than $1+$ group abundance, presumably because the seabird distribution surveys were carried out in June, when birds are feeding mainly on 0 group. Two studies have indicated that environmental and fishery effects are additive in influencing kittiwake breeding success (Frederiksen et al. 2004; Scott et al. 2006). It is likely that fishery closure benefitted kittiwakes by improving conditions for 1+ group sandeels, while environmental conditions were more favourable for 0 group sandeels after closure. Our data support ICES's selection of kittiwake breeding success as an indicator of sandeel abundance (ICES 1999, 2001). However, the precise mechanism linking kittiwake breeding success to variation in sandeel abundance and fishing activity remains unclear.

There was also evidence that gannet consumption rate and at-sea distribution were related to 0 group abundance. Like kittiwakes, gannets have limited abilities to exploit the water column, but can range widely, so diet composition and behaviour may be a reliable indicator of sandeel abundance (Hamer et al. 2006). Breeding success of gannets is considered less sensitive than that of kittiwakes because of their large size, greater capacity to switch prey, and larger foraging range (Furness and Tasker 2000; Hamer et al. 2000). However, gannet breeding success is not routinely monitored, and thus it is not possible to determine whether productivity is buffered against fluctuations in sandeel abundance.

We could detect no significant relationship between either $1+$ group or 0 group abundance and consumption rate, usage of the study area, or breeding success of the other study species (i.e., shag, guillemot, razorbill, puffin, terns). Although detecting no impact in these species does not unequivocally confirm a lack of fishery effect, the foraging ecologies of these species may explain why they are less likely to be affected by sandeel abundance in the study area than kittiwakes or gannets. Shags and terns use the study area comparatively little. Furthermore, sandeels represented only a third of the diet of terns. While shags were almost completely dependent on sandeels during the study, their capacity to exploit the water column may buffer them against changing prey abundance (Furness and Tasker 2000; Daunt et al. 2006). The auks use the study area much more extensively, but like shags can exploit the water column. The importance of diving capacity is hard to quantify because of a lack of information on the depth distribution of 0 group and 1+ group sandeels. However, diving species will have access to a greater proportion of the sandeel population than surface-feeding species such as kittiwakes, making them potentially less affected by a decline in absolute abundance. Diving ability may also be important if fisheries cause a redistribution of sandeels to deeper depths.

Monitoring of seabird breeding performance in the area continued in 2004 (Mavor et al. 2005) and 2005 (Parsons 2005), and success was poor across all species in 2004 and all except kittiwakes in 2005, despite the continued closure of sandeel fishing in the area. Sandeel abundance at the North Sea scale was low in those 2 years (ICES 2005a, 2006), and a total ban on fishing was imposed on the North Sea starting 1 July 2005. The available data from these 2 years suggest that the relationship between sandeel abundance and the wider seabird community may be stronger than our study has found. However, data on sandeel abundance at the fine scale presented here are not available in 2004 and 2005, so it is not known whether sandeel abundance in the study area matched estimates at the North Sea scale.

\section{Management implications}

By selecting habitat hotspots as no-take zones, important populations of target species can be safeguarded, providing potential benefits for top predators. A rapid response in target species abundance is particularly likely among shortlived, sedentary species (Gell and Roberts 2003; Sale et al. 2005), such as sandeels. Following closure of a sandeel fishery along the east coast of Great Britain, there was an immediate increase in sandeel abundance (Greenstreet et al. 2006). This increase was most likely the result of improved survival of $1+$ group sandeels, previously the target of the fishery, combined with coincidental high levels of recruitment (Greenstreet et al. 2006). We recorded a marked improvement in breeding success of kittiwakes associated with sandeel fishery closure. This is an encouraging outcome, since the kittiwake has been in substantial decline in recent years (Frederiksen et al. 2004). However, more knowledge is urgently required on the mechanisms linking fisheries, sandeel abundance, and kittiwake breeding success. Our results also demonstrated the lack of generality in the response of different seabird predators to fishery closure in accordance with their contrasting foraging ecologies, since we could not detect a benefit of sandeel fishery closure in the other sandeel-specialist species.

Our study suggests that fishery closures should be considered as a potential management option for the conservation of marine top predators that are sensitive to changes in the abundance of sedentary, short-lived prey species targeted by fisheries, such as kittiwakes preying on sandeels in this study. However, the effectiveness of closures will depend on the environmental conditions experienced before and after closure takes place. Furthermore, no-take reserves are less likely to have a beneficial impact on predators that are buffered against changes in target species abundance, for example those with diving ability, large foraging range, or the capacity to switch to other prey species. It is critical that monitoring across a 
range of trophic levels continues, complemented by research to identify the functional relationships among oceanography, primary and secondary production, forage fish, top predators, and fisheries. Only in this way will high-quality data on ecosystem function become available to management (FAO 2002; Ormerod 2003; DEFRA 2005).

\section{Acknowledgements}

The authors thank the many people who collected seabird data, especially Suki Finney, Jenny Bull, Linda Wilson, Sue Lewis, Liz Humphreys, and Janos Hennicke, and the landowners for access to field sites, in particular Scottish Natural Heritage (Isle of May) and Sir Hew Hamilton-Dalrymple (Bass Rock). Iain Gibb provided assistance with aging sandeels, and Helen Fraser and Gayle Holland helped with seabird surveys. The authors are grateful to the officers and crew of FRV Clupea and other scientists at the Marine Laboratory for assistance with seabird surveys. David Elston, Morten Frederiksen, and Sue Lewis gave statistical advice and commented on the manuscript. This work was funded by the Joint Nature Conservation Committee, Scottish Executive, and the EU (ELIFONTS, DGXIV 95/78; MIFOS, CFP 96-079; IMPRESS, Q5RS-2000-30864; PROTECT, FP6-2003-SSP-3-513670).

\section{References}

Arnott, S.A., and Ruxton, G.D. 2002. Sandeel recruitment in the North Sea: demographic, climatic and trophic effects. Mar. Ecol. Prog. Ser. 238: 199-210.

Bull, J., Wanless, S., Elston, D.A., Daunt, F., Lewis, S., and Harris, M.P. 2004. Local-scale variability in the diet of black-legged kittiwakes Rissa tridactyla. Ardea, 92: 43-52.

Camphuysen, C.J. 2005. Seabirds at sea in summer in the northwest North Sea. Brit. Birds, 98: 2-19.

Dalskov, J. 2002. Description of the Danish monitoring scheme for the small meshed fishery in the North Sea, Skagerrak and Kattegat. Danish Institute for Fisheries Research (DIFRES) report, Charlottenlund, Denmark.

Daunt, F., Benvenuti, S., Harris, M.P., Dall'Antonia, L., Elston, D.A., and Wanless, S. 2002. Foraging strategies of black-legged kittiwakes Rissa tridactyla at a North Sea colony: evidence for a maximum foraging range. Mar. Ecol. Prog. Ser. 245: 239-247.

Daunt, F., Wanless, S., Peters, G., Benvenuti, S., Sharples, J., Gremillet, D., and Scott, B. 2006. Impacts of oceanography on the foraging dynamics of seabirds in the North Sea. In Top predators in marine ecosystems: their role in monitoring and management. Edited by I.L. Boyd, S. Wanless, and C.J. Camphuysen. Cambridge University Press, Cambridge, UK. pp. 177-190.

DEFRA. 2005. Charting progress: an integrated assessment of the state of UK seas. Department for Environment, Food and Rural Affairs, London, UK.

Enstipp, M.R., Daunt, F., Wanless, S., Humphreys, E., Hamer, K.C., Benvenuti, S., and Grémillet, D. 2006. Foraging energetics of North Sea birds confronted with fluctuating prey availability. In Top predators in marine ecosystems: their role in monitoring and management. Edited by I.L. Boyd, S. Wanless, and C.J. Camphuysen. Cambridge University Press, Cambridge, UK. pp. 191-210.

European Commission. 2000. Council Regulation (EC) No. 850/98 of 30 March 1998 for the conservation of fishery resources through technical measures for the protection of juveniles of marine organisms. Amended by Council Regulation (EC) No.
1298/2000 on 8 June 2000, Brussels, Belgium. Available from ec.europa.eu/fisheries/legislation/other/conservation2003_en.htm [accessed December 2006; updated 16 February 2007].

FAO. 2002. The state of world fisheries and agriculture. Food and Agriculture Organisation of the United Nations (FAO), Rome, Italy.

Frederiksen, M., Wanless, S., Harris, M.P., Rothery, P., and Wilson, L.J. 2004. The role of industrial fishery and oceanographic change in the decline of North Sea black-legged kittiwakes. J. Appl. Ecol. 41: 1129-1139.

Furness, R.W. 1982. Competition between seabird communities. Adv. Mar. Biol. 20: 225-307.

Furness, R.W. 2002. Management implications of interactions between fisheries and sandeel-dependent seabirds and seals in the North Sea. ICES J. Mar. Sci. 59: 261-269.

Furness, R.W., and Tasker, M.L. 2000. Seabird-fishery interactions: quantifying the sensitivity of seabirds to reductions in sandeel abundance, and identification of key areas for sensitive seabirds in the North Sea. Mar. Ecol. Prog. Ser. 202: 354-364.

Gauld, A. 1990. Movements of lesser sandeels (Ammodytes marinus Riatt) tagged in the northwestern North Sea. J. Cons. Int. Explor. Mer, 46: 229-231.

Gell, F.R., and Roberts, C.M. 2003. Benefits beyond boundaries: the fishery effects of marine reserves. Trends Ecol. Evol. 18: 448-455.

Greenstreet, S.P.R. 2006. Does the prohibition of industrial fishing for sandeels have any impact on local gadoid populations? In Top predators in marine ecosystems: their role in monitoring and management. Edited by I.L. Boyd, S. Wanless, and C.J. Camphuysen. Cambridge University Press, Cambridge, UK. pp. 223-235.

Greenstreet, S.P.R., Armstrong, E., Mosegaard, H., Jensen, H., Gibb, I., Fraser, H., Scott, B., Holland, G., and Sharples, J. 2006. Variation in the abundance of sandeels Ammodyes marinus off southeast Scotland: an evaluation of area-closure fisheries management and stock abundance assessment methods. ICES J. Mar. Sci. 63: 1530-1550.

Hamer, K.C., Phillips, R.A., Wanless, S., Harris, M.P., and Wood, A.G. 2000. Foraging ranges, diets and feeding locations of gannets Morus bassanus in the North Sea: evidence from satellite telemetry. Mar. Ecol. Prog. Ser. 200: 257-264.

Hamer, K.C., Lewis, S., Wanless, S., Phillips, R.A., Sherratt, T.N., Humphreys, E.M., Hennicke, J., and Garthe, S. 2006. Use of gannets to monitor prey availability in the NE Atlantic Ocean: colony size, diet and foraging behaviour. In Top predators in marine ecosystems: their role in monitoring and management. Edited by I.L. Boyd, S. Wanless, and C.J. Camphuysen. Cambridge University Press, Cambridge, UK. pp. 236-248.

Harris, M.P., and Wanless, S. 1997. Breeding success, diet, and brood neglect in the kittiwake (Rissa tridactyla) over an 11 year period. ICES J. Mar. Sci. 54: 615-623.

Holland, G.J., Greenstreet, S.P.R., Gibb, I.M., Fraser, H.M., and Robertson, M.R. 2005. Identifying sandeel Ammodytes marinus sediment habitat preferences in the marine environment. Mar. Ecol. Prog. Ser. 303: 269-282.

ICES. 1999. Report of the study group on the effects of sandeel fishing. International Council for the Exploration of the Sea, Copenhagen, Denmark. ICES CM 1999/ACFM:19.

ICES. 2001. Report of the Advisory Committee on Ecosystems 2001. International Council for the Exploration of the Sea, Copenhagen, Denmark. ICES Coop. Res. Rep. 249.

ICES. 2004. Report of the Advisory Committee on Fishery Management and Advisory Committee on Ecosystems 2004. International Council for the Exploration of the Sea, Copenhagen, Denmark. ICES Advice, Vol. 1, No. 2. 
ICES. 2005a. Report of the working group on the assessment of demersal stocks in the North Sea and Skagerrak 2004. International Council for the Exploration of the Sea, Copenhagen, Denmark. ICES CM 2005/ACFM:07.

ICES. 2005b. Report of the study group on multispecies assessments in the North Sea 2005. International Council for the Exploration of the Sea, Copenhagen, Denmark. ICES CM 2005/D:06.

ICES. 2006. Report of the working group on the assessment of demersal stocks in the North Sea and Skagerrak 2005. International Council for the Exploration of the Sea, Copenhagen, Denmark. ICES CM 2006/ACFM:09.

Lewis, S., Wanless, S., Wright, P.J., Harris, M.P., Bull, J., and Elston, D.A. 2001. Diet and breeding performance of blacklegged kittiwakes Rissa tridactyla at a North Sea colony. Mar. Ecol. Prog. Ser. 221: 277-284.

Lewis, S., Hamer, K.C., Money, L., Griffiths, R., Wanless, S., and Sherratt, T.N. 2004. Brood neglect and contingent foraging behaviour in a pelagic seabird. Behav. Ecol. Sociobiol. 56: 81-88.

Mavor, R.A., Parsons, M., Heubeck, M., and Schmitt, S. 2005. Seabirds numbers and breeding success in Britain and Ireland. UK Nature Conservation 29. Joint Nature Conservation Committee, Peterborough, UK.

Monaghan, P. 1992. Seabirds and sandeels: the conflict between exploitation and conservation in the northern North Sea. Biodiv. Conserv. 1: 98-111.

Monaghan, P., Uttley, J.D., Burns, M.D., Thaine, C., and Blackwood, J. 1989. The relationship between food supply, reproductive effort and breeding success in Arctic Terns Sterna paradisaea. J. Anim. Ecol. 58: 261-274.

Ormerod, S.J. 2003. Current issues with fish and fisheries: editor's overview and introduction. J. Appl. Ecol. 40: 204-213.

Parsons, M. 2005. UK seabirds in 2005. Joint Nature Conservation Committee, Peterborough, UK.

Proctor, R., Wright, P.J., and Everitt, A. 1998. Modelling the transport of larval sandeels on the north-west European shelf. Fish. Oceanogr. 7: 347-354.

Rindorf, A., Wanless, S., and Harris, M.P. 2000. Effects of changes in sandeel availability on the reproductive output of seabirds. Mar. Ecol. Prog. Ser. 202: 241-252.

Sale, P.F., Cowen, R.K., Danilowicz, B.S., Jones, G.P., Kritzer, J.P., Lindeman, K.C., Planes, S., Polunin, N.V.C., Ruse, G.R., Sadovy, Y.J., and Steneck, R.S. 2005. Critical science gaps impede use of no-take fishery reserves. Trends Ecol. Evol. 20: 74-80.

Scott, B.E., Sharples, J., Wanless, S., Ross, O., Frederiksen, M., and Daunt, F. 2006. The use of biologically meaningful oceanographic indices to separate the effects of climate and fisheries on seabird breeding success. In Top predators in marine ecosystems: their role in monitoring and management. Edited by I.L. Boyd, S. Wanless, and C.J. Camphuysen. Cambridge University Press, Cambridge, UK. pp. 46-62.

Sharples, J., Ross, O.N., Scott, B.E., Greenstreet, S.P.R., and Fraser, H. 2006. Inter-annual variability in the timing of stratification and the spring bloom in the north-western North Sea. Cont. Shelf Res. 26: 733-751.

Tasker, M.L., Jones, P.H., Dixon, T.J., and Blake, B.F. 1984. Counting seabirds from ships: a review of methods employed and a suggestion for a standardized approach. Auk, 101: 567-577.

Tasker, M.L., Hope Jones, P., Blake, B.F., and Dixon, T.J. 1985. The marine distribution of the gannet Sula bassana in the North Sea. Bird Study, 32: 82-90.

Wanless, S., Harris, M.P., and Morris, J.A. 1990. A comparison of feeding areas used by individual common murres (Uria aalge), razorbills (Alca torda) and an Atlantic puffin (Fratercula arctica) during the breeding season as shown by radio tracking. Colon. Waterbirds, 13: 16-24.

Wanless, S., Harris, M.P., and Morris, J.A. 1991. Foraging range and feeding locations of shags Phalacrocorax aristotelis during chick rearing. Ibis, 133: 30-36.

Wanless, S., Harris, M.P., and Greenstreet, S.P.R. 1998. Summer sandeel consumption by seabirds breeding in the Firth of Forth, south-east Scotland. ICES J. Mar. Sci. 55: 1141-1151.

Wanless, S., Wright, P.J., Harris, M.P., and Elston, D.A. 2004. Evidence of a decrease in size of lesser sandeels Ammodytes marinus in a North Sea aggregation over a 30-yr period. Mar. Ecol. Prog. Ser. 279: 237-246.

Wanless, S., Daunt, F., Camphuysen, C.J., Humphreys, E., and Hamer, K.C. 2005. Setting the scene: seabird foraging behaviour, diet and breeding success. In Interactions between the marine environment, predators, and prey: implications for sustainable sandeel fisheries (IMPRESS). Edited by C.J. Camphuysen. Final Report to EU, Texel, The Netherlands. pp. 88-134.

Webb, A., and Durinck, J. 1992. Counting birds from ship. In Manual for aeroplane and ship surveys of waterfowl and seabirds. Edited by J. Komdeur, J. Bertelsen, and G. Cracknell. International Waterfowl and Wetlands Research Bureau (IWRB), Slimbridge, UK. IWRB Spec. Publ. 19. pp. 24-37.

Wilson, L.J., Daunt, F., and Wanless, S. 2004. Self feeding and chick provisioning diet differ in the common guillemot Uria aalge. Ardea, 92: 197-207.

Winslade, P. 1974. Behavioural studies on the lesser sandeel Ammodytes marinus (Raitt) II. The effect of light intensity on activity. J. Fish Biol. 6: 577-586.

Wright, P.J. 1996. Is there a conflict between sandeel fisheries and seabirds? A case study in Shetland. In Aquatic predators and their prey. Edited by S.P.R. Greenstreet and M.L. Tasker. Fishing News Books, Oxford, UK. pp. 154-165.

Wright, P.J., and Bailey, M.C. 1996. Timing of hatching in Ammodytes marinus from Shetland waters and its significance to early growth and survivorship. Mar. Biol. 126: 143-152.

Wright, P.J., and Begg, G.S. 1997. A spatial comparison of common guillemots and sandeels in Scottish waters. ICES J. Mar. Sci. 54: 578-592.

Wright, P.J., Jensen, H., and Tuck, I. 2000. The influence of sediment type on the distribution of the lesser sandeel Ammodytes marinus. J. Sea Res. 44: 243-256.

Wright, P.J., Jensen, H., Mosegaard, H., Dalskov, J., and Wanless, S. 2002. European Commission's annual report on the impact of the Northeast sandeel fishery closure and status report on the monitoring fishery in 2000 and 2001. Report to EC DG XIV. FRS Marine Laboratory, Aberdeen, Scotland, UK.

\section{Appendix A. Parameters in consumption model: methods}

\section{Population size and attendance of breeding adults, immature birds, and chicks}

Breeding population sizes were available in the literature (Mitchell et al. 2004; annual reports for Forth Islands (e.g. Jones 2004) and St Abbs Head (e.g. Rideout and Sheard 2003)). Complete annual counts were made of all shag and kittiwake colonies, with the exception of the Berwick and Angus coasts. These two areas were counted in 2000 only (Mitchell et al. 2004), and counts for the other years were obtained by scaling the 2000 count to the changes in population size in colonies counted in all years. Northern gannets 
were counted in 1994 (Murray and Wanless 1997) and 2004 (Wanless et al. 2005b), and an annual estimate of population size was derived by assuming a constant rate of change over the period. Guillemots and razorbills were counted annually at all colonies with the exception of St Abbs Head, the Berwick coast, and the Angus coast. At St Abbs Head, a complete count was made in 1998 and 2003, and counts for the other years were derived from annual counts of long-term monitoring plots. Guillemots and razorbills were counted on the Berwick and Angus coasts in 2000 only, and correction factors were made for the remaining years by scaling to the changes in populations counted in all years. For both these species, the typical monitoring method is to count the number of individuals rather than nesting pairs (Walsh et al. 1995). The number of pairs in the study area was converted from counts of individuals using correction factors available annually on the Isle of May (e.g. Charras and Parkinson 2003). Counts of puffins were carried out at the main breeding colony (the Isle of May) in 1998 and 2003, and the numbers of breeding pairs in the remaining years were estimated by assuming a constant rate of change over the period (Harris et al. 2003). All other colonies were counted at least once during the study period, with a complete count carried out in 2003 (Harris et al. 2003). For colonies with more than one count, counts for others years were obtained by assuming constant rates of change between counts. For colonies counted in 2003 only, counts for other years were obtained by scaling the 2003 count to the changes in the Isle of May population. A complete count of terns was made annually at all colonies (e.g. Charras and Parkinson 2003), with the exception of 2002. In this year, estimates for these colonies were scaled to the 2003 count by the ratio of population size of counted colonies in 2002 and 2003. It was not possible to estimate the nonbreeding component of the adult population. We therefore assumed that all adults bred, and accordingly our estimates for consumption are likely to be slightly underestimated.

Breeding adults of each species were assumed to be foraging in the study area during the following periods: shag, 1 April - 31 August; gannet, 1 April - 31 August; kittiwake, 1 April - 10 August; guillemot, 1 April - 20 July; razorbill, 1 April - 20 July; puffin, 1 April - 10 August; terns, 1 May 31 July (after Wanless et al. 1998).

The population size of immature birds was derived from a simple population model that calculated the juvenile survival and the proportion of the total population in each age class during the study period. Estimates of mean adult survival (Nisbet and Cam 2000; Harris et al. 2000; Frederiksen et al. 2004; Wanless et al. 2006), mean breeding success (see below), mean recruitment age (Aebischer 1986; Gaston and Jones 1998; Lebreton et al. 2003; Frederiksen et al. 2004; Wanless et al. 2006), and mean population growth rate (see above) were used. We assumed that immature birds within 2 years of mean recruitment age were present in the study area on the basis that colony attendance during the breeding season commences in the years prior to recruitment (e.g. Bradley et al. 1999). The component of the population represented by each attending immature age class was summed and expressed as a proportion of the total number of breeding adults. We further assumed that the seasonal attendance of immature birds was the same as that of adults in the model, with the exception of kittiwake, guillemot, razorbill, and puffin in April (no immature birds generally present) and puffin and kittiwake in August (two-thirds immature birds present; after Wanless et al. 1998).

The number of chicks present in the area each year was obtained from the product of the breeding population size and breeding success. Breeding success data were available for shags, kittiwakes, guillemots, razorbills, puffins, and common and arctic terns in all years from the Isle of May (e.g. Wilson et al. 2003; Charras and Parkinson 2003), and for sandwich terns in the 3 years that they bred on the Isle of May (2000, 2001 and 2003). Roseate tern breeding success was unknown. The breeding success of common and arctic terns is a combined estimate because it was not possible to separate the young of the two species at fledging (Charras and Parkinson 2003). A single breeding success estimate for terns was determined by taking the mean of the commonarctic and sandwich tern breeding success weighted on population size. Additionally, shag and kittiwake breeding success was recorded annually at St Abbs Head (e.g. Rideout and Sheard 2003); a mean annual breeding success weighted by population size at the two colonies was derived for these two species. Breeding success data were only available for the gannet in 2003 (Wanless et al. 2005a). The value recorded in 2003 was similar to the long-term average (Nelson 2002) and so was used in all other years. Chicks were present in the model for the duration of the nestling period, and annual timing of consumption was determined from median hatching dates (own data). Chicks that were lost prior to fledging were not included in the model.

\section{Diet}

Months for which data were available are listed under each species. For most species, data were available in June and July, but less frequently in April, May, and August. All data were collected on the Isle of May unless otherwise stated. For each seabird species, data were expressed as the proportion of the biomass consisting of 0 group and $1+$ group sandeels.

For species that carry food in their stomachs, and from which diet was determined from regurgitations by adults and chicks (shags, gannets, kittiwakes), biomass proportions of each prey type were derived for each food sample using methods in Lewis et al. (2001). Briefly, an initial assessment of diet composition was made and the food sample weighed. The sample was digested in biological washing powder, and remaining otoliths and fish bones were identified using keys (Härkönen 1986; Watt et al. 1997; Leopold et al. 2001). For sandeel otoliths, age class was determined from otolith macrostructure using counts of annuli (ICES 1995). The length of each fish was back-calculated from otolith diameter. For sandeels, a year-specific fish length to otolith length relationship was derived each season by flight-netting puffins carrying fish to their chicks and by collecting fish dropped on ledges by adult guillemots. These sandeels were sorted into $5 \mathrm{~mm}$ total length classes (range: $35-170 \mathrm{~mm}$ ). For each length class, otoliths were extracted and measured using the method described above, and the data was used to determine year- and age-specific ( 0 group and $1+$ group) relationships between fish length and otolith length. For other prey species, species-specific (but not year-specific) fish length to otolith 
length (or width) relationships were obtained from Härkönen (1986). The energetic value of each fish was estimated from energy to length equations in Harris and Hislop (1978) and Hislop et al. (1991). The biomass proportions of 0 group and $1+$ group sandeels were calculated for each food sample.

For guillemot, razorbill, puffin, and terns, diet information was obtained by observing adults returning to the colony with prey in their bills. The method of determining biomass proportions of 0 group and $1+$ sandeels depended on whether the species was flight-netted or observed from a hide. For logistical reasons, flight-netting was only possible for puffins. For guillemots, razorbills, and terns, observations enable the prey species and a length class (five, four, and three categories, respectively) to be determined, based on fish length relative to bill length. These sizes were confirmed each year by collecting fish dropped on the breeding ledges. Precise derivation of prey biomass for razorbills is problematic because it carries multiple prey items in its bill, and the number of prey in loads is hard to quantify. We know from observations that if there is more than one fish in the load, the number is inversely related to the unit prey size. Accordingly, we assumed that loads containing very small, small, medium, and large fish comprised 10, 6, 4, and 2 individual prey, respectively. Sandeels were aged on size, with all individuals in the smallest category (for guillemot) and two smallest categories (for razorbill and terns) assigned to 0 group, and all those in the remaining categories assigned to $1+$ group. The energetic value of each prey was estimated from energy to length equations in Harris and Hislop (1978) and Hislop et al. (1991), and biomass proportions of 0 group and 1+ group sandeel were calculated for each food sample. For puffins, the length of each fish was measured and divided into 0 group and $1+$ group using discriminant analysis (details in Wanless et al. 2004). Biomass proportions were determined for each sample as described above.

For all species carrying prey in their bill, adult diet was assumed to be the same as chick diet, with the exception of guillemot. In all years, diet in May was derived from display fish brought to the colony by adults. In addition, in 2003 a sample of breeding adults were caught during May and June, and the food present in the stomach was obtained by wateroffloading (under UK Home Office Licence, Wilson et al. 2004). The biomass of each age class of sandeel was derived in the same way as regurgitates from shags, gannets, and kittiwakes. Diet of adults differed considerably from that brought to the chicks (Wilson et al. 2004). Furthermore, water-offloading of adult guillemots has been carried out in subsequent years, under UK Home Office Licence, and the same difference between adult and chick diet was apparent (F. Daunt, unpublished data). Therefore, this difference was assumed to have occurred in all years.

The available data were as follows:

(a) Shag: June-July 1996, 1998, 2000, 2001, and 2002; May-July 1997; and June 2003 (e.g. Wilson et al. 2003).

(b) Gannet: June-August 1998 and 2001; July-August 2002; and June-July 2003 from the Bass Rock (Hamer et al. 2000; Lewis et al. 2003, Wanless et al. 2005a).

(c) Kittiwake: April-July 1998; and May-July in all other years on the Isle of May (e.g. Wilson et al. 2003). In addition, diet data were available in July 1997, 1998, and 2000 at Inchcolm and in July 1997-1999 at Inchkeith
(Bull et al. 2004). A mean diet composition for these months weighted on population size at the three colonies was derived.

(d) Guillemot: May-July in all years (e.g. Wilson et al. 2003).

(e) Razorbills: June-July in all years (e.g. Wilson et al. 2003).

(f) Puffin: May-July in all years (Wanless et al. 2004). However, the data in May were only from the end of the month and were therefore merged with the June data.

( $g$ ) Terns: June in all years (e.g. Charras and Parkinson 2003).

To calculate overall consumption, we had to make the following assumptions where data were missing. First, for April and May, the same proportion of 1+ group were present as was present in the diet in June of that year. Second, all 0 group in the June-August diet were assumed to have been replaced by $1+$ group in April and May, when 0 group sandeels are still in larval form and there is no evidence that they are consumed by seabirds to any great extent. This diet switch has been demonstrated in the kittiwake (Lewis et al. 2001), guillemot (Wilson et al. 2004), and gannet (Hamer et al. 2000; Lewis et al. 2003; Wanless et al. 2005a) and is therefore likely to occur in other species that feed extensively on 0 group sandeels from June onwards. Third, for missing data in June, July, or August, diet was assumed to be the same as data available for those months in the same year. To calculate overall consumption among years, we used the monthly mean of years in which data were available for those years where diet data were completely absent.

\section{Assimilation efficiency}

Assimilation efficiency was available for shag (adults), kittiwakes (adults and chicks), guillemots (adults), razorbill (adults), puffin (adults), and arctic tern (chicks) with a range of 0.74-0.81 (Gabrielsen et al. 1992; Klaasen et al. 1992; Hilton et al. 2000). For gannet, we used a value for cape gannet (Morus capensis) chicks (Cooper 1978). The empirical data available were used for all age classes of the species, with adult kittiwake assimilation efficiency used for immature birds.

\section{Energy expenditure}

Empirical values for daily energy expenditure (DEE) were available for shags (adults, Enstipp et al. 2006), gannets (adults, Birt-Friesen et al. 1989), kittiwakes (adults and chicks, Humphreys 2002), guillemots (adults, Cairns et al. 1990; chicks, G.W. Gabrielsen, unpublished data), and arctic terns (adults, Uttley et al. 1994; chicks, Klaasen 1994). Values for razorbills and puffins were taken from Birt-Friesen et al. (1989) (DEE $=11.455 \cdot$ mass $^{0.727}$, for seabirds using flapping flight in cold waters). DEE for chicks was derived from observed daily food intakes (gannets, Montevecchi et al. 1984; razorbill and puffin, Harris and Wanless 1986) or allometric equations (shag, Weathers 1992).

\section{Energy density of prey}

Annual estimates of calorific value for 0 group and 1+ group sandeels were derived from the fish collected from puffins, detailed above. Energy density $\left(\mathrm{kJ} \cdot \mathrm{g}^{-1}\right)$ was calculated by dividing calorific value by mass (derived from mass = 0.00209.length ${ }^{3.148}$; Harris and Hislop 1991). 


\section{References}

Aebischer, N.J. 1986. Retrospective investigation of an ecological disaster in the shag, Phalacrocorax aristotelis - a general method based on long-term marking. J. Anim. Ecol. 55: 613-629.

Birt-Friesen, V.L., Montevecchi, W.A., Cairns, D.K., and Macko, S.A. 1989. Activity-specific metabolic rates of free-living northern gannets and other seabirds. Ecology, 70: 357-367.

Bradley, J.S., Gunn, B.M., Skira, I.J., Mearthel, C.E., and Wooller, R.D. 1999. Age-dependent prospecting and recruitment to a breeding colony of short-tailed shearwaters Puffinus tenuirostris. Ibis, 141: 277-285.

Bull, J., Wanless, S., Elston, D.A., Daunt, F., Lewis, S., and Harris, M.P. 2004. Local-scale variability in the diet of black-legged kittiwakes Rissa tridactyla. Ardea, 92: 43-52.

Cairns, D.K., Montevecchi, W.A., Birt-Friesen, V.L., and Macko, S.A. 1990. Energy expenditures, activity budgets, and prey harvest of breeding common murres. Stud. Avian Biol. 14: 84-92.

Charras, Y., and Parkinson, I. 2003. Studies of breeding birds and other biological recording on the Isle of May, 2003. Scottish Natural Heritage, Cupar, UK.

Cooper, J. 1978. Energetic requirements for growth and maintenance of the Cape gannet. Zool. Afr. 13: 305-317.

Enstipp, M.R., Daunt, F., Wanless, S., Humphreys, E., Hamer, K.C., Benvenuti, S., and Grémillet, D. 2006. Foraging energetics of North Sea birds confronted with fluctuating prey availability. In Top predators in marine ecosystems: their role in monitoring and management. Edited by I.L. Boyd, S. Wanless, and C.J. Camphuysen. Cambridge University Press, Cambridge, UK. pp. 191-210.

Frederiksen, M., Wanless, S., Harris, M.P., Rothery, P., and Wilson, L.J. 2004. The role of industrial fishery and oceanographic change in the decline of North Sea black-legged kittiwakes. J. Appl. Ecol. 41: 1129-1139.

Gabrielsen, G.W., Klaasen, M., and Mehlum, F. 1992. Energetics of black-legged kittiwake (Rissa tridactyla) chicks. Ardea, 80: 29-40.

Gaston, A.J., and Jones, I.L. 1998. The auks. Oxford University Press, Oxford, UK.

Hamer, K.C., Phillips, R.A., Wanless, S., Harris, M.P., and Wood, A.G. 2000. Foraging ranges, diets and feeding locations of gannets Morus bassanus in the North Sea: evidence from satellite telemetry. Mar. Ecol. Prog. Ser. 200: 257-264.

Härkönen, T. 1986. Guide to the otoliths of the bony fishes of the Northeast Atlantic. Danbiu ApS, Hellerup, Denmark.

Harris, M.P., and Hislop, J.R.G. 1978. The food of young puffins Fratercula arctica. J. Zool. 185: 213-236.

Harris, M.P., and Wanless, S. 1986. The food of young razorbills on the Isle of May and a comparison with that of young guillemots and puffins. Ornis Scand. 17: 41-46.

Harris, M.P., Wanless, S., and Rothery, P. 2000. Adult survival rates of shag Phalacrocorax aristotelis, common guillemot Uria aalge, razorbill Alca torda, puffin Fratercula arctica and kittiwake Rissa tridactyla on the Isle of May 1986-1996. Atlantic Seabirds, 2: 133-150.

Harris, M.P., Wanless, S., Murray, S., Leitch, A., and Wilson, L.J. 2003. Counts of Atlantic Puffins Fratercula arctica in the Firth of Forth, south-east Scotland in 2003. Atlantic Seabirds, 5: 101-111.

Hilton, G.M., Furness, R.W., and Houston, D.C. 2000. A comparative study of digestion in North Atlantic seabirds. J. Avian Biol. 31: $36-46$.

Hislop, J.R.G., Harris, M.P., and Smith, J.G.M. 1991. Variation in the calorific value, and total energy content of lesser sandeels (Ammodytes marinus) and other fish preyed on by seabirds. J. Zool. 224: 501-517.
Humphreys, E.M. 2002. Energetics of spatial exploitation of the North Sea by kittiwakes breeding on the Isle of May, Scotland. Ph.D. thesis, Department of Biological Sciences, Universty of Stirling, UK.

ICES. 1995. Report of the ICES workshop on sandeel otolith analysis: review of sandeel biology. International Council for the Exploration of the Sea, Copenhagen, Denmark. ICES CM 1995/G:4.

Jones, D. 2004. Forth Islands bird report 2003. Forth Seabird Group Annual Report, Firth of Forth, UK.

Klaasen, M. 1994. Growth and energetics of tern chicks from temperate and polar environments. Auk, 111: 240-248.

Klaasen, M., Zwaan, P., Heslenfeld, P., Lucas, P., and Luijckx, B. 1992. Growth rate associated changes in the energy requirements of tern chicks. Ardea, 80:19-28.

Lebreton, J.-D., Hines, J.E., Pradel, R., Nichols, J.D., and Spendelow, J.A. 2003. Estimation by capture-recapture of recruitment and dispersal over several sites. Oikos, 101: 253-264.

Leopold, M.F., Van Damme, C.J.G., Philippart, C.J.M., and Winter, C.J.N. 2001. Otoliths of North Sea fish: fish identification key by means of otoliths and other hard parts. World Biodiversity Database CD-ROM Series. Expert Center for Taxonomic Identification, Amsterdam, The Netherlands.

Lewis, S., Wanless, S., Wright, P.J., Harris, M.P., Bull, J., and Elston, D.A. 2001. Diet and breeding performance of blacklegged kittiwakes Rissa tridactyla at a North Sea colony. Mar. Ecol. Prog. Ser. 221: 277-284.

Lewis, S., Sherratt, T.N., Hamer, K.C., Harris, M.P., and Wanless, S. 2003. Contrasting diet quality in northern gannets at two different colonies. Ardea, 91: 167-176.

Mitchell, I.P., Newton, S.F., Ratcliffe, N., and Dunn, T.E. (Editors). 2004. Seabird populations of Britain and Ireland. T. and A.D. Poyser, London, UK.

Montevecchi, W.A., Ricklefs, R.E., Kirkham, I.R., and Gabaldon, D. 1984. Nestling energetics of northern gannets. Auk, 101: 334-341.

Murray, S., and Wanless, S. 1997. The status of the gannet in Scotland in 1994-5. Scottish Birds, 19: 10-27.

Nelson, J.B. 2002. The Atlantic gannet. Fenix Books Ltd., Norfolk, UK.

Nisbet, I.C.T., and Cam, E. 2000. Test for age-specificity in survival of the common tern. J. Appl. Stat. 29: 65-83.

Rideout, K., and Sheard, K. 2003. St Abb's Head annual report 2003 to Scottish Natural Heritage (Forth and Borders). Scottish Natural Heritage, Galashiels, UK.

Uttley, J., Tatner, P., and Monaghan, P. 1994. Measuring daily energy expenditure of free-living terns (Sterna paradisaea). Auk, 111: 453-459.

Walsh, P.M., Halley, D.J., Harris, M.P., del Nevo, A., Sim, I.M.W., and Tasker, M.L. 1995. Seabird monitoring handbook for Britain and Ireland. JNCC/RSPB/ITE/Seabird Group, Peterborough, UK.

Wanless, S., Harris, M.P., and Greenstreet, S.P.R. 1998. Summer sandeel consumption by seabirds breeding in the Firth of Forth, south-east Scotland. ICES J. Mar. Sci. 55: 1141-1151.

Wanless, S., Wright, P.J., Harris, M.P., and Elston, D.A. 2004. Evidence of a decrease in size of lesser sandeels Ammodytes marinus in a North Sea aggregation over a $30-y r$ period. Mar. Ecol. Prog. Ser. 279: 237-246.

Wanless, S., Daunt, F., Camphuysen, C.J., Humphreys, E. and Hamer, K.C. $2005 a$. Setting the scene: seabird foraging behaviour, diet and breeding success. In Interactions between the marine environment, predators, and prey: implications for sustainable sandeel fisheries (IMPRESS). Edited by C.J. Camphuysen. Final Report to EU, Texel, The Netherlands. pp 88-134. 
Wanless, S., Murray, S., and Harris, M.P. 2005b. The status of Northern Gannet in Britain and Ireland in 2003/04. Brit. Birds, 98: $280-294$.

Wanless, S., Frederiksen, M., Harris, M.P., and Freeman, S.N. 2006. Survival of northern gannets Morus bassanus in Britain and Ireland, 1959-2001. Bird Study, 53: 79-85.

Watt, J., Pierce, G.J., and Boyle, P.R. 1997. Guide to the identification of North Sea fish using premaxillae and vertebrae. International Council for the Exploration of the Sea, Copenhagen, Denmark. ICES Coop. Res. Rep. No. 220.

Weathers, W.W. 1992. Scaling nestling energy requirements. Ibis, 134: $142-153$.

Wilson, L.J., Wanless, S., Harris, M.P., and Jones, G. 2003. Isle of May seabird studies in 2003. Joint Nature Conservation Committee (JNCC), Aberdeen, UK. Rep. No. 362.

Wilson, L.J., Daunt, F., and Wanless, S. 2004. Self feeding and chick provisioning diet differ in the common guillemot Uria aalge. Ardea, 92: 197-207.

\section{Appendix B. Parameters in consumption model: results}

There were marked interspecific differences in population status over the study period, with an increase in the number of shags, gannets, guillemots, and puffins; a decline in kittiwakes and razorbills; and fluctuating numbers of terns (Fig. B1). The overall number of seabirds breeding in the study area (Fig. B1) increased largely because of the increases in gannets, guillemots, and puffins. The estimated size of the immature populations were as follows: shag, $36.4 \%$ of the number of breeding individuals; gannet, $23.8 \%$; kittiwake, $11.2 \%$; guillemot, $10.6 \%$; razorbill, $17.0 \%$; puffin, $19.1 \%$; and terns, $17.9 \%$. Breeding success was variable throughout the study period for all species except shags at both colonies and kittiwakes at one colony (the Isle of May), where breeding success increased, and guillemots, where there was evidence of a decline (Table B1; note that data for gannets was only available in 2003 and for sandwich terns in 2000, 2001, and 2003).

As expected, sandeels were important in the diet of all species. 1+ group sandeels were the main prey item of shags (Table B2), with 0 group sandeels being almost completely absent. 0 group sandeels were of minor importance in the diet of guillemot chicks, but were well represented in the diet of adult guillemots, although less important than $1+$ group sandeels. Both age classes were of equal importance in the diet of kittiwakes, razorbills, and puffins, composing $77 \%-87 \%$ of biomass for these species. They were also of similar, though lesser combined, importance in the diet of terns $(34 \%)$ and gannets $(42 \%)$.

Figure B1 and Tables B1 and B2 appear on the following pages. 
Fig. B1 Annual breeding population counts (breeding pairs) for each species and all species combined. The northern gannet was counted in 1994 and 2004, and the data for other years were modelled from these counts. The other six species were counted in most years throughout the study period (see Appendix A for exceptions). Species are as follows: shag (European shag, Phalacrocorax aristotelis); gannet (northern gannet, Morus bassanus); kittiwake (black-legged kittiwake, Rissa tridactyla); guillemot (common guillemot, Uria aalge); razorbill (Alca torda); puffin (Atlantic puffin, Fratercula arctica); terns (common tern, Sterna hirundo; arctic tern, Sterna paradisaea; roseate tern, Sterna dougallii; sandwich tern, Sterna sandvicensis).

(a) shag

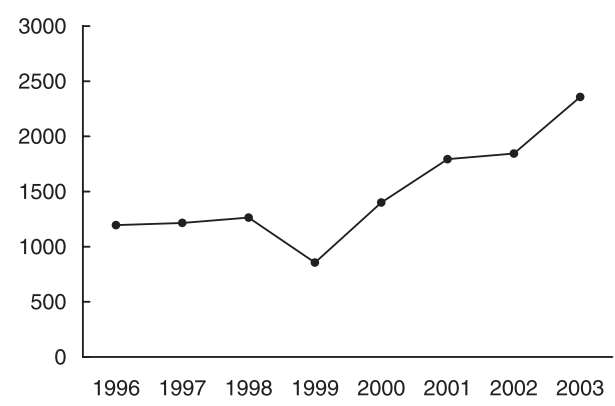

(c) kittiwake

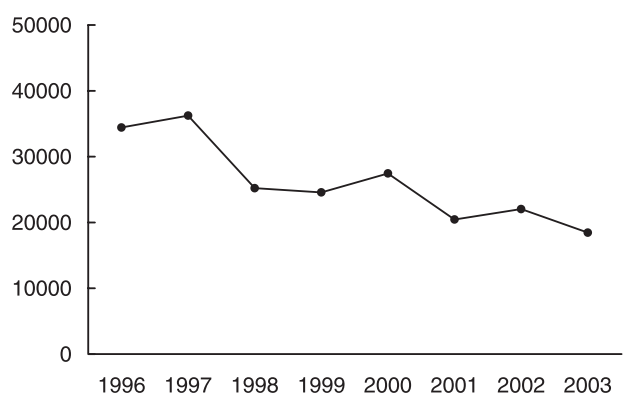

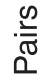

(e) razorbill

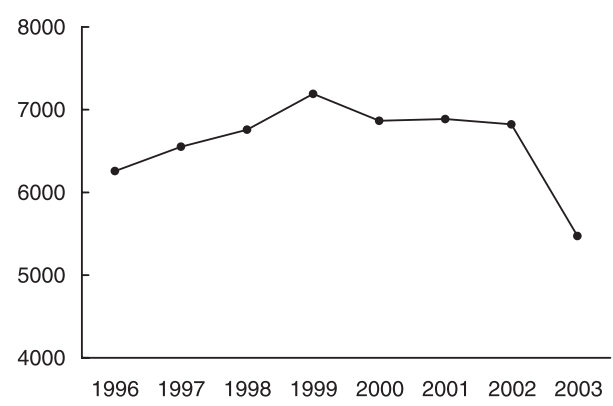

(g) terns

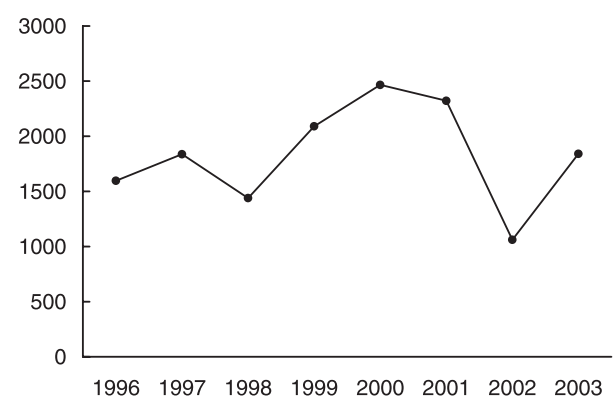

(b) gannet

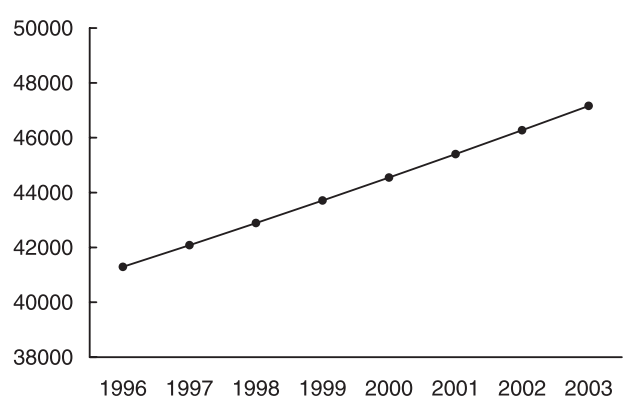

(d) guillemot

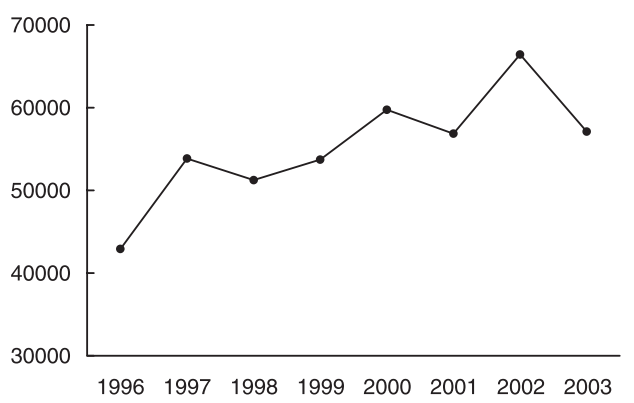

(f) puffin

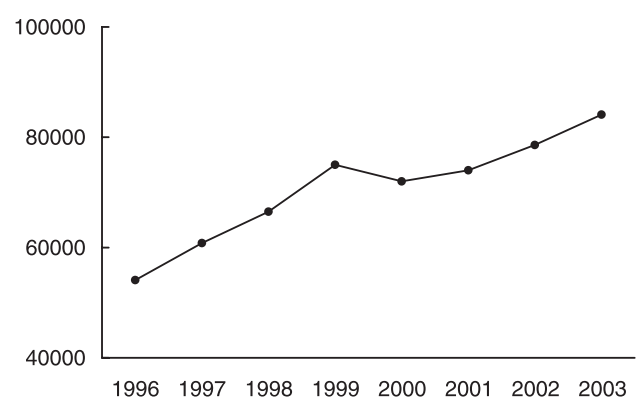

(h) all species

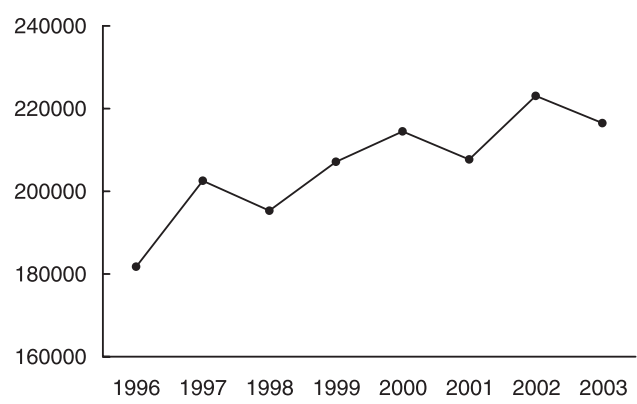


Table B1. Mean breeding success (chicks per pair) of each seabird species over the study period.

\begin{tabular}{|c|c|c|c|c|c|c|c|c|c|c|}
\hline \multirow[b]{2}{*}{ Year } & \multicolumn{2}{|l|}{ Shag } & \multirow[t]{2}{*}{ Gannet } & \multicolumn{2}{|c|}{ Kittiwake } & \multirow[t]{2}{*}{ Guillemot } & \multirow[t]{2}{*}{ Razorbill } & \multirow[t]{2}{*}{ Puffin } & \multirow{2}{*}{$\begin{array}{l}\text { Common- } \\
\text { arctic tern* }\end{array}$} & \multirow{2}{*}{$\begin{array}{l}\text { Sandwich } \\
\text { tern }\end{array}$} \\
\hline & IoM & St A & & IoM & $\overline{\text { St A }}$ & & & & & \\
\hline 1996 & 1.05 & 1.69 & - & 0.56 & 1.06 & 0.82 & 0.63 & 0.78 & 0.30 & - \\
\hline 1997 & 0.98 & 0.50 & - & 0.40 & 0.68 & 0.77 & 0.70 & 0.65 & 0.35 & - \\
\hline 1998 & 0.69 & 0.97 & - & 0.02 & 0.27 & 0.73 & 0.57 & $0.74^{\dagger}$ & 0.30 & - \\
\hline 1999 & 0.33 & 0.81 & - & 0.20 & 0.60 & 0.66 & 0.52 & 0.58 & 0.50 & - \\
\hline 2000 & 1.48 & 1.60 & - & 0.97 & 0.80 & 0.73 & 0.68 & 0.73 & 0.66 & 1.00 \\
\hline 2001 & 1.53 & 1.60 & - & 0.61 & 0.40 & 0.63 & 0.60 & 0.78 & 0.12 & 0.50 \\
\hline 2002 & 1.66 & 1.60 & - & 0.47 & 0.33 & 0.68 & 0.64 & 0.72 & 0.00 & - \\
\hline 2003 & 1.83 & 1.77 & 0.69 & 0.77 & 0.98 & 0.69 & 0.58 & 0.78 & 0.29 & 0.31 \\
\hline
\end{tabular}

Note: Estimates were available for shag and kittiwake from two colonies: IoM, Isle of May; St A, St Abbs.

*Common and arctic tern breeding success is a combined estimate because the young of these two species could not be separated.

${ }^{\dagger}$ Final estimate was 0.54, allowing for $27 \%$ mortality late in the season (Harris and Wanless 1998).

Table B2. Annual proportions of 0 group and 1+ group lesser sandeel (Ammodytes marinus) biomass taken by each study species.

\begin{tabular}{|c|c|c|c|c|c|c|c|c|c|c|c|c|c|c|c|c|}
\hline \multirow[b]{2}{*}{ Year } & \multicolumn{2}{|l|}{ Shag } & \multicolumn{2}{|c|}{ Gannet } & \multicolumn{2}{|c|}{ Kittiwake } & \multicolumn{2}{|c|}{$\begin{array}{l}\text { Guillemot } \\
\text { (colony) }\end{array}$} & \multicolumn{2}{|c|}{$\begin{array}{l}\text { Guillemot } \\
\text { (adult) }\end{array}$} & \multicolumn{2}{|c|}{ Razorbill } & \multicolumn{2}{|c|}{ Puffin } & \multicolumn{2}{|c|}{ Tern spp. } \\
\hline & 0 & $1+$ & 0 & $1+$ & 0 & $1+$ & 0 & $1+$ & 0 & $1+$ & 0 & $1+$ & 0 & $1+$ & 0 & $1+$ \\
\hline 1997 & 0.00 & 1.00 & - & - & 0.41 & 0.49 & 0.03 & 0.64 & - & - & 0.53 & 0.39 & 0.39 & 0.47 & 0.25 & 0.20 \\
\hline 1998 & 0.00 & 0.97 & 0.13 & 0.20 & 0.40 & 0.41 & 0.00 & 0.28 & - & - & 0.35 & 0.45 & 0.42 & 0.42 & 0.13 & 0.22 \\
\hline 1999 & - & - & - & - & 0.46 & 0.39 & 0.00 & 0.36 & - & - & 0.29 & 0.47 & 0.23 & 0.27 & 0.09 & 0.16 \\
\hline 2002 & 0.02 & 0.95 & 0.34 & 0.23 & 0.53 & 0.34 & 0.00 & 0.41 & - & - & 0.41 & 0.41 & 0.37 & 0.56 & 0.52 & 0.26 \\
\hline 2003 & 0.01 & 0.95 & 0.24 & 0.22 & 0.61 & 0.34 & 0.00 & 0.26 & 0.28 & 0.57 & 0.48 & 0.37 & 0.43 & 0.40 & 0.07 & 0.17 \\
\hline Mean & 0.01 & 0.95 & 0.23 & 0.19 & 0.46 & 0.41 & 0.00 & 0.35 & 0.28 & 0.57 & 0.36 & 0.41 & 0.38 & 0.43 & 0.17 & 0.17 \\
\hline
\end{tabular}

Note: Values for each year are means of 5 months (April-August).

\section{Reference}

Harris, M.P., and Wanless, S. 1998. Isle of May seabird studies in 1998. Joint Nature Conservation Committee Report (JNCC), Aberdeen, UK. Rep. No. 282. 